\title{
Review Article \\ Research Survey on Various MPPT Performance Issues to Improve the Solar PV System Efficiency
}

\author{
B. Pakkiraiah and G. Durga Sukumar \\ Department of Electrical and Electronics Engineering, Vignan's Foundation for Science, Technology and Research University, \\ Guntur 522213, India \\ Correspondence should be addressed to B. Pakkiraiah; pakki1988@gmail.com
}

Received 4 February 2016; Accepted 8 June 2016

Academic Editor: Sundaram Senthilarasu

Copyright (C) 2016 B. Pakkiraiah and G. D. Sukumar. This is an open access article distributed under the Creative Commons Attribution License, which permits unrestricted use, distribution, and reproduction in any medium, provided the original work is properly cited.

\begin{abstract}
Nowadays in order to meet the increase in power demands and to reduce the global warming, renewable energy sources based system is used. Out of the various renewable energy sources, solar energy is the main alternative. But, compared to other sources, the solar panel system converts only $30-40 \%$ of solar irradiation into electrical energy. In order to get maximum output from a PV panel system, an extensive research has been underway for long time so as to access the performance of PV system and to investigate the various issues related to the use of solar PV system effectively. This paper therefore presents different types of PV panel systems, maximum power point tracking control algorithms, power electronic converters usage with control aspects, various controllers, filters to reduce harmonic content, and usage of battery system for PV system. Attempts have been made to highlight the current and future issues involved in the development of PV system with improved performance. A list of 185 research publications on this is appended for reference.
\end{abstract}

\section{Introduction}

As the earth natural resources are decreasing day by day, to meet the increase in the power demand, the power sector is looking at alternate energy resources. Due to usage of renewable energy sources, the carbon content in the atmosphere can be reduced by which global warming problem can be overcome. Out of various renewable sources, solar PV system is leading nowadays due to its simple structure. The various structure of PV panel system and its suitability for locations have been discussed [1-7]. The efficiency of the PV system can be increased by using power electronic devices along with maximum power point controller. The extraction of maximum available power from a photovoltaic module is done by Maximum Power Point Tracking Controller. The efficiency of the photovoltaic system may be substantially increased by using maximum power point tracker (MPPT). Several algorithms are developed to track the maximum power point efficiently. Most of the existing MPPT algorithms suffer from the drawback of being slow tracking. Due to this, the utilization efficiency is reduced. The various methods of maximum power point technique algorithms such as Incremental Conductance (INC) and Perturbation and Observation ( $\mathrm{P} \& \mathrm{O})$ have been discussed [8-56].

The output obtained from the MPPT controller contains harmonics due to the closed loop tracking of sun light. This can be eliminated by using the filter circuits. From this, the obtained output is given to power electronic devices DCDC converter and inverter. The various power electronic converters circuits and the control techniques are discussed [57-66]. In this paper, the literature survey has been done on various aspects of the solar PV fed system drives. In Section 2 the various types of PV panel systems which are available and their performances and suitability are presented. The Maximum Power Point Tracking Controllers and their performances have been discussed in Section 3. Power electronic circuits and their controlling using various controlling techniques are reviewed in Section 4. The harmonic reduction of PV panel system using filter circuit is presented in Section 5. In Section 6 the battery and inverters are discussed. The concluding remarks are stated in Section 7. 


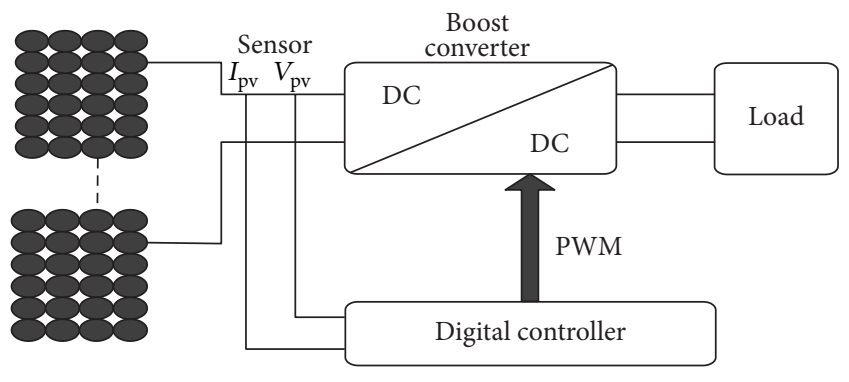

FIGURE 1: Block diagram of PV generation systems.

\section{Photovoltaic System}

A photovoltaic (PV) system is solid state semiconductor devices which generates electricity when it is exposed to the light. The building of a solar panel is solar cell. A photovoltaic module is formed by connecting many solar cells in series and parallel. To get maximum output voltage, PV modules are connected in series and for obtaining maximum output current they are connected in parallel. Solar PV power systems have been commercialized in many countries due to their merits such as long term benefits and maintenancefree. The major challenge which lies in using the PV power generation systems is to tackle the nonlinear characteristics of PV array. The PV characteristics depend on the level of irradiance and temperature. PV array experiences different irradiance levels due to passing clouds, neighbor buildings, or trees. The block diagram of PV generation system is shown in Figure 1.

Photovoltaic systems are mainly classified as per their functionality and operation of systems, component configurations, and the equipment connected to electrical loads. They are mainly classified as grid connected and standalone systems which are designed to provide DC and AC power service to operate with independence of the utility grid that are connected with other energy sources and storage systems.

2.1. Grid Connected PV System. The grid connected PV systems are designed to operate in parallel and connected with the electric utility grid system. They mainly consist of inverter in order to convert array produced DC into AC power with voltage and power quality requirements of the utility grid. A bidirectional interface made between the PV system AC output circuits and electric utility network at onsite distribution panel or service entrance to allow AC power to either supply or feed back the grid when the PV system output is greater than load demand [67]. The block diagram of a grid connected PV system is observed from given Figure 2.

PV system is capable of operating in grid connected and standalone modes using multilevel inverter and boost converter for extracting maximum power and fed it to the utility grid and standalone system [3].

2.2. Standalone Photovoltaic Systems. These are mainly designed to operate independently of the electric utility grid and designed size to supply certain DC or AC electric loads.
The simple type of standalone PV system is a direct-coupled system. This operates only during sunlight hours and energy will not be stored in battery system. Main application is such as ventilation fans, water pumps, and small pumps for solar thermal water heating systems [67]. Block diagram of a direct-coupled PV system is as shown in Figure 3.

For the above direct-coupled PV system, several studies such as continuous variations of solar radiation, quality of load matching, geographical location, climatic studies, degree of utilization, and accurate sizing are investigated to various loads [68-72]. Cristaldi et al. [73] have observed the behavior of the PV panel from a direct-coupled system with switchedmode converter and MPP algorithm. They have compared $V-I$ characteristics of the panel with and without MPP algorithm. The design methodology in this study is mainly based on the variation of solar radiation; due to this, the results could not be safely applied over a period of time for specific input radiation time series. Another type of standalone PV system powering DC and AC loads with battery storage system [74] is as shown in Figure 4.

One more form is PV hybrid systems which most commonly take the form of the photovoltaic systems combined with wind turbines or diesel generators mostly found in Canary Island [75]. The block diagram of PV hybrid system is shown in Figure 5.

PV panels are connected in series parallel combinations to the inverter; the difference in panel voltages can cause problems such as location of global MPP at different positions under partially and fully shaded atmospheric conditions. To overcome this, optimizers are installed on each panel. This allows them to work independently from one another, optimizes energy output, and enables us to monitor the performance of each module. A standalone system incorporates a photovoltaic panel, regulator, energy storage system, and load [76].

Giral et al. [77] have explained the minimization of shadow effect in a two-section module PV system by using active voltage sharing. It is observed that the active bypass does not produce losses under nonshadow/matching conditions. Siddique et al. [78] presented the loss analysis in the conventional AC configuration for large PV farms and proposed two DC collector grid configurations to increase the overall yield of plant with reducing the overall cost by making it a potentially viable option to increase the energy yield and revenue of the plant.

Yordanov et al. [79] have presented the analysis of series resistance corrected load ideality factor between MPP open circuits for several types of crystalline-silicon technologies. This analysis is made to study more about the PV device's performances. Han and Jia [80] have implemented the mathematical model of photovoltaic cell and characteristics curves of solar cell based on MPPT technologies with stable and accurate maximum power point by improving the control precision. Here also a disturbance is based on four corners detecting module to delay; opening and closing characteristics are observed. Ibrahim and Basir [81] have proposed the multistage SVR algorithm to avoid outdoor irradiation and temperature. It consists of three stages of algorithm for irradiation, temperature, and voltage with incentive ambient 


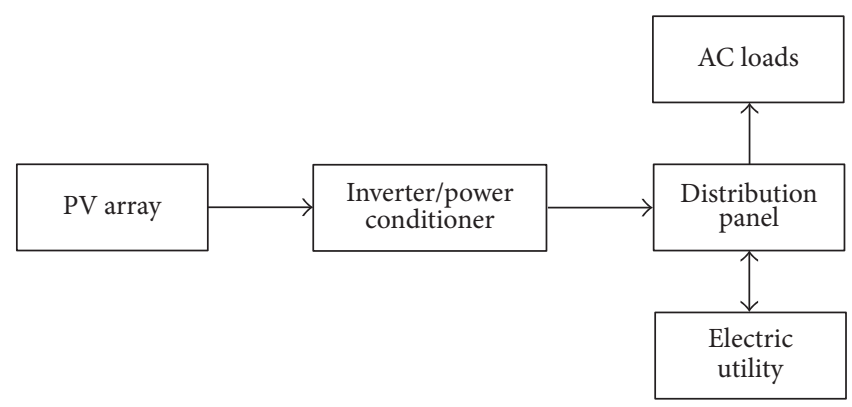

FIGURE 2: Block diagram of grid connected PV system.

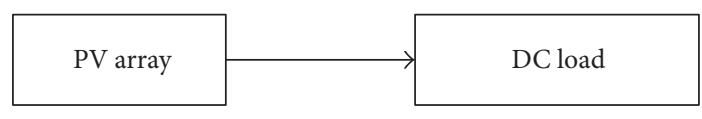

FIGURE 3: Block diagram of direct-coupled PV system.

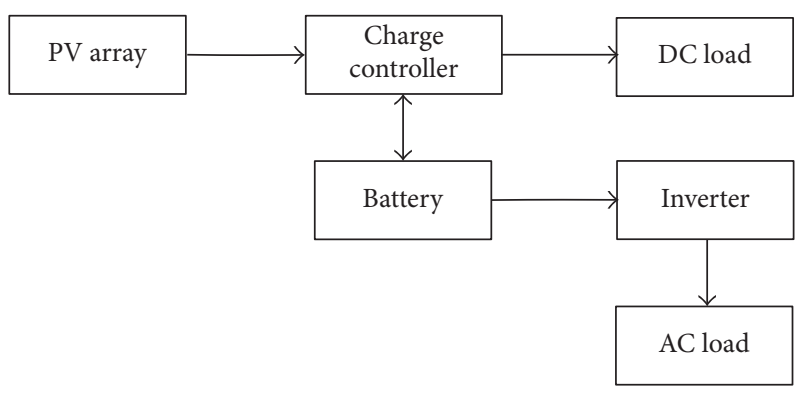

FIGURE 4: Standalone PV system with battery storage powering DC and AC loads.

temperature variations. Here the incorporation of partial shading effect of PV arrays is not carried out.

\section{Maximum Power Point Tracking}

Maximum power point tracking control technique is used mainly to extract maximum capable power of the PV modules with respective solar irradiance and temperature at particular instant of time by Maximum Power Point Tracking Controller. A number of algorithms are developed to track the maximum power point efficiently. Most of the existing MPPT algorithms suffer from the drawback of being slow tracking, due to which the utilization efficiency is reduced. There are several types of MPPT control techniques to improve the solar energy efficiency such as Incremental Conductance (INC) [8-35], Hill Climbing or Perturbation and Observation (P\&O) [36-56], Artificial Neural Network (ANN) with back propagation technique [82-97], Fuzzy Logic Controller Intelligent Control (FLCIC) with DC-DC converter [33, 98-111], Particle Swarm Optimization [112120], Open Circuit Voltage Control (OCVC), Short-Circuit Current Control (SCCC), feedback of power variation with voltage technique, feedback of power variation with current technique, single input fuzzy controller for tracking MPP, Ant Colony Optimization (ACO), and Genetic Algorithm

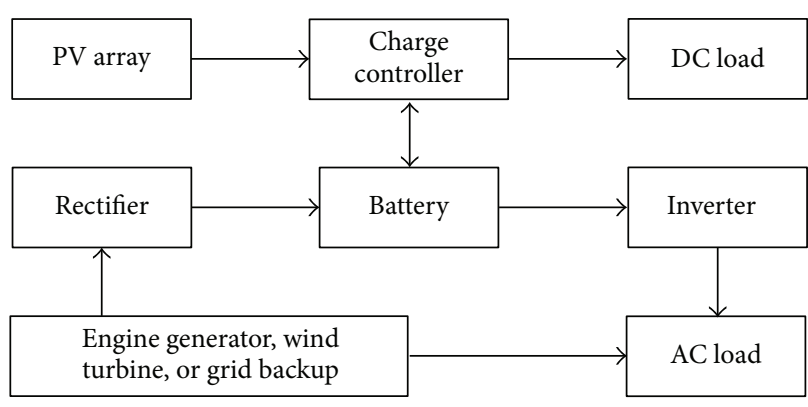

FIGURE 5: Block diagram of PV hybrid system.

(GA) methods. The appearance of multipeak output curves of partial shading in PV arrays is common, where the development of an algorithm for accurately tracking the true MPPs of the complex and nonlinear output curves is crucial.

$\mathrm{Wu}$ et al. [121] say that the MPPT regulates the output obtained from the PV system and provides that output to the DC converter and inverter. If the PV output voltage is higher than MPP, then the power transferred to the load or network is increased. Piegari and Rizzo [122] have discussed the MPPT techniques for different applications for different individual systems. The MPPT efficiency varies depending on cell temperature and fill factor. Azli et al. [123] propose the MPPT performance which improves with the temperature of the PV system; the $4 \%$ of the efficiency is affected by the variations of the fill factor with the climatic conditions and features of geographic region. Tauseef and Nowicki [124] have presented the modeling of MPPT with buck converter with oscillations less than $0.5 \%$ in the output power. Also the PV cell with two-diode model for MPPT controller relies on the fact that the ratio of $V_{\mathrm{mpp}} / V_{\mathrm{oc}}$ does not strongly depend on the environmental conditions.

Mattavelli et al. [125] have implemented the single chip IC circuit for MPPT to interface the PV panel with batteries and inverters to utility grid and the transient response of the system has been verified with the step DC voltage to check the MPPT response for PV short-circuit current variations. Al-Bahadili et al. [126] discuss the computer simulation to evaluate the performance of MPPT algorithm for PV energy system to carry different PV technologies and also to demonstrate an excellent and flexible environment for studying various PV solar cells operating at different 


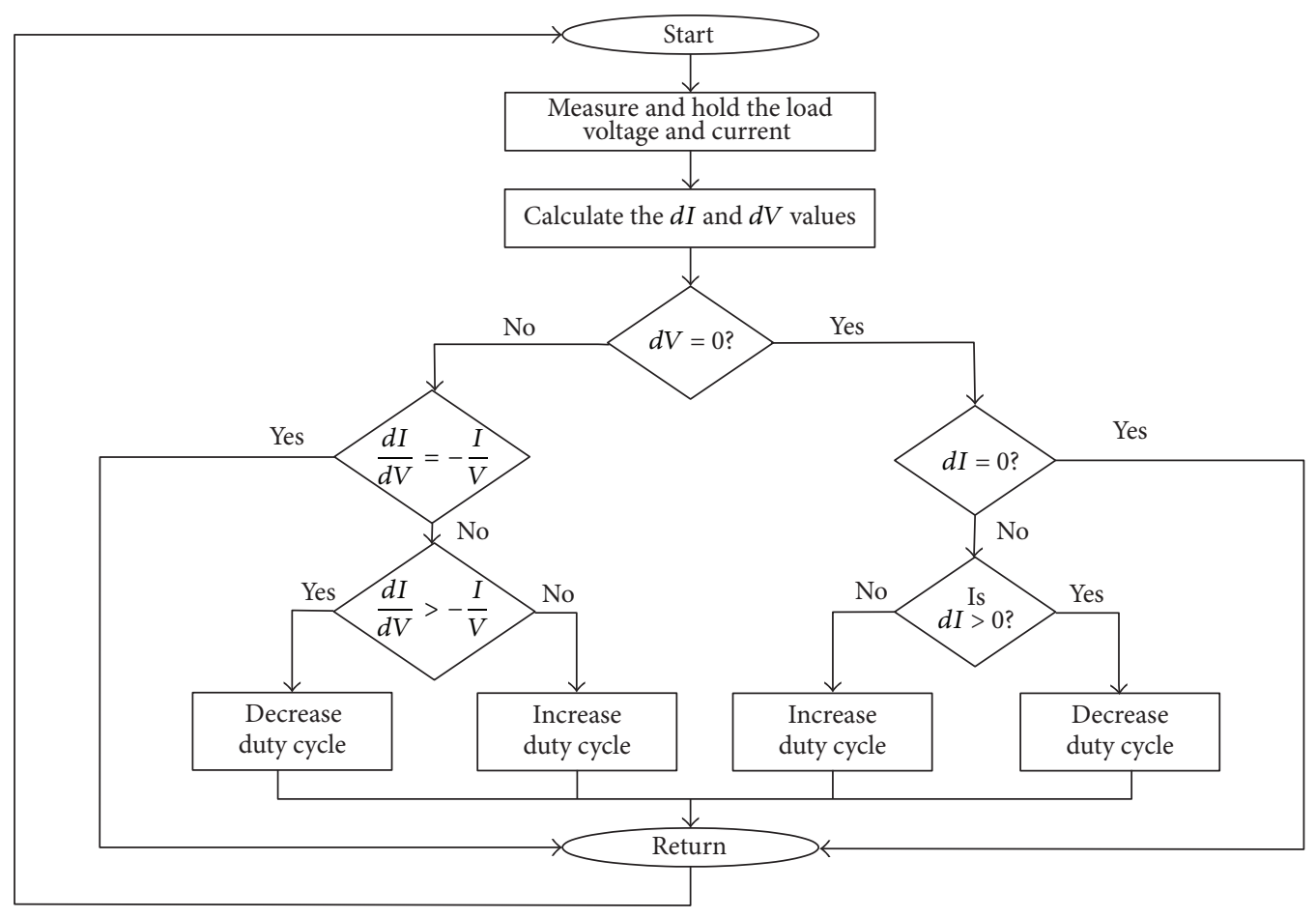

FIgURE 6: Flowchart of IC algorithms for MPPT.

environments of irradiance and temperature. Wu et al. [127] have proposed the MPPT method performances to the MPPT structure and cost in the common insolation condition is to reach the efficiency of $98 \%$ of the real maximum output power. Ropp and Gonzalez [128] have discussed the aspects of PV inverters accuracy consisting of detection behavior and the action of maximum power point tracker response to grid voltage and frequency fluctuations introduced by the PV array. Brando et al. [129] have explained the sensor less control of $\mathrm{H}$ bridge multilevel converter for MPPT in grid connected PV systems to deliver maximum power for variations of incident irradiations on PV arrays with the $H$ bridge 5-level converter to reduce the current oscillations up to $1 \%$ though the voltage slope changes. Khan and Hossain [130] have explained the implementation of MPP algorithm in an 8-bit microcontroller to generate optimized real time code in C.

Kadri et al. [131] have discussed the voltage control MPPT to reduce the power losses caused by dynamic tracking errors under rapid weather changing conditions. Also the grid current components for reflecting the power grid side and the signal error of a PI outer voltage regulation reflect the change in power by the irradiation variation for identifying the correct direction of MPP. Thao and Uchida [132] have proposed a method to the controller for PV 1-phase grid connected system with rated power $1 \mathrm{~kW}$ for great performances in seeking the MPP of the PV array which regulates the DC link voltage and also reaches unity power factor even if the solar irradiance and temperature vary abruptly.

3.1. Incremental Conductance (INC) Based MPPT Techniques. The techniques are proposed to obtain MPP operating point for an adaptive voltage step changes based on the slope of the $\mathrm{PV}$ curve. To get changes in voltage step value from the PV curve acceleration and deceleration factors are applied in the next iteration steps. The adaptive voltage step change enables the PV system to quickly track the environment condition variations. In this way more solar energy can be harvested from the PV energy systems. It is easy to implement since it does not require knowledge of $I-V$ characteristics of specific PV panels and the parameters are easy to tune [8-16]. The MPP is tracked by searching the peak of the $P-V$ curve. This algorithm uses the instantaneous conductance $I / V$ and $d I / d V$ for MPPT. Using these two values, the algorithm determines the location of the operating point of the PV module in the $P-V$ curve showing that the PV module operates at the MPP along with left and right sides of the MPP in the $P-V$ curve [17-22]. Flow chart of the algorithm is as shown in Figure 6.

Liu et al. [19] presented the variable step size INC algorithm to increase the tracking speed of the MPPT controller. Incremental Conductance method determines the radiation direction to do voltage changing under rapidly changing condition; in addition, it also calculates the MPP. Thus, oscillation problem of P\&O algorithm around MPP would have been eliminated. For uniform radiation condition, there is no significant difference between the efficiencies of these two methods [24, 25]. Incremental Conductance method was determined to operate with more efficiency under randomly generated conditions [26]. However, the cost of INC method is high due to requirements of high sampling compliance and speed control as a result of complex structure. Classically, INC method is the mostly used technique as a part in Hill Climbing algorithm, but it has the drawback in decision making as the speed increases in proportion to the step 
size of the error. However, higher error step size reduces the efficiency of MPPT and direction errors under rapid atmospheric changes in [27]. One of the major difficulties implementing the INC method is the selection of the fixed voltage change step size for simultaneously satisfying the tracking speed and maintaining the MPP. A large step size of the voltage change helps the system rapidly approach the MPPs. On the other hand, this large value generally induces persisting oscillations around the MPP if no other special countermeasures were taken. The issues using a small step size of voltage change are the opposite.

Liu et al. [28] have presented an improved Incremental Conductance (INC) algorithm which uses variable voltage step size to estimate the trade-off between the dynamic responses and trade-off between the dynamic response and steady state oscillation with respect to size of the step. This reduces the oscillations and improves the converter energy efficiency of PVPS and also the design issues of the variable step size parameters are discussed. Yusof et al. [29] have developed algorithm using C-programming such that having ability to withstand parameter variation such as temperature variations and variable voltage from the battery. This method gives very good boosting capability from PV source to the load by the $V_{\text {MPPT }}$ simulation.

Murtaza et al. [30] have explained the comparison between four basic MPPT techniques under steady as well as environmental varying conditions with the MATLAB model. Out of these methods, INC gives the good dynamic performances with respect to change in weather conditions. And it is found that the INC is complex for implementation with two sensors as far as the efficiency and power losses are concerned. Keyrouz and Georges [31] have implemented the multidimensional MPPT in PV systems under dynamically changing weather conditions based on fusion of two algorithms. Wolfs and Li [32] explained the MPPT based Incremental Conductance method to meet the MPP of the solar cell output voltage and the converter duty ratio without current sensor. By comparing Hill Climbing or Perturbation and Observation and Incremental Conductance methods, the cell voltage is perturbed for every MPPT cycle and also cell output power is calculated. To overcome the oscillations in Incremental Conductance method, perturb-and-observe based MPPT algorithm is used. A triple junction solar cell model is established in simulation process to validate a tracking theoretical performance analysis.

Adly et al. [33] have tested the Incremental Conductance for the PV models under fast changing environmental conditions by using DC-DC converter as isolation stage through the load connected $\mathrm{PV}$ at the required maximum power point voltage. $15 \%$ energy extraction losses can be saved. Yu et al. [34] discussed dependency of MPP on temperature and solar isolation. In this different MPPT control methods to draw maximum power from solar array such as the constant voltage control, Incremental Conductance conditions twomode MPPT control algorithm. Al Nabulsi et al. [35] have presented Hill Climbing using Incremental Conductance for tracking maximum power point to get maximum output power of a PV panel. Here the optimum duty cycle results in maximum power delivered from the PV panel through
DC/DC converter to the load. But here the operating point of PV array oscillates around the MPP with causing of power loss.

3.2. Perturbation and Observation Based MPPT Algorithm. The Perturbation and Observation MPPT algorithm is easy to implement; it works based on the PV array which is perturbed of a radiation of direction. If the power drained from the array increases, the operating point varies towards the MPP which in turn suits therefore the working voltage in the similar direction. If the power drained from the PV array decreases, the operating point varies away from the MPP, and thus the direction of the working voltage perturbation has to be overturned [36-39]. A disadvantage of P\&O MPPT method is at steady state. The operating point oscillates in the region of the MPP giving rise to the waste of energy. A number of improvements of the $\mathrm{P} \& \mathrm{O}$ algorithm have been deliberate in order to decrease the oscillations in steady state, but this slows down the speed of response of the algorithm during the atmospheric changes. Go et al. [40] discuss power oscillations in $\mathrm{P} \& \mathrm{O}$ algorithm that the array terminal voltage perturbed every MPPT cycle. Liu et al. [41] have proposed solution of decoupling the PV power fluctuations caused by the Hill Climbing P\&O process from the variations of the irradiance to solve the oscillation problem. In this the incremental change in power $\Delta P$ is measured. If the $\Delta P$ value is positive, the operating voltage is increased to get MPP; if the value of $\Delta P$ is negative, the direction of voltage adjustment is reversed and operating point in trying to make it is the closest to MPP [42]. The flow chart algorithm is shown in Figure 7.

However, the applications of analog circuits using $\mathrm{P} \& \mathrm{O}$ algorithm are presented in [43]. Al-Amoudi and Zhang [44] have proposed a variable step size that gradually moves towards MPP. But this method is not adaptive because the steps are varied in predetermined way. A model based approach is given by Zhang et al. [45] to measure the PV array temperature and irradiance. In the specific set of irradiance and temperature measurements, a DC voltage value is predicted so that PV array can deliver maximum output. A variable perturbation is proposed in [46]; in this four-power range adopted, a specific perturbation value is used in each range, but it changes continuously in a real time. Therefore, this method is not fully adaptive. Fast tracking is obtained using larger step size due to this greater oscillations are obtained in $[47,48]$, where converter duty ratio is perturbed instead of array voltage or current.

Petrone et al. [49] discussed a multivariable P\&O MPPT technique for single stage PV inverter. Though it performs well, the need for controlling more than one variable increases the complexity of the operation. Jung et al. [50] have proposed the improved Perturbation and Observation method with adaptive algorithm to adjust the reference voltage step size and hysteresis in constant or slowly varying atmospheric conditions to reduce the PV output power up to $5 \%$ compared to the traditional $\mathrm{P} \& \mathrm{O}$ in the unsettled weather conditions.

Suganya and Carolin Mabel [51] have modeled and analyzed the photovoltaic system based on Perturbation and Observation MPPT method to maximize the PV array output 


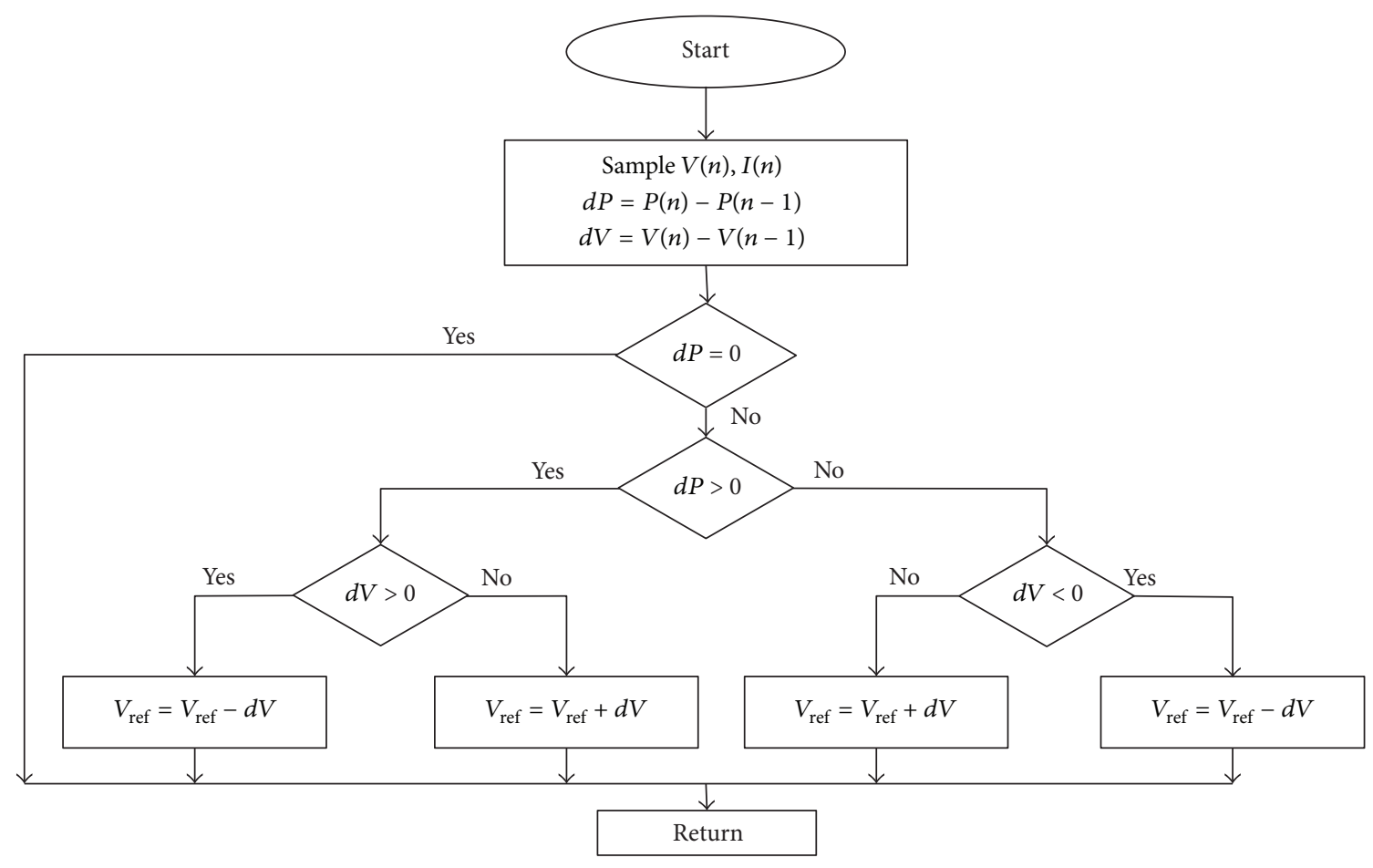

Figure 7: Flow chart of Perturbation and Observation method.

power by tracking the MPP continuously. It improved the MPPT algorithm under the same irradiation condition. Radwan and Orabi [52] discussed optimizing of P\&O algorithm parameters to get the dynamic behavior of the PV system. Here also some drawbacks are observed, about the oscillations of the operating point around the MPP. Practically, the nonideality of the DC-DC converter is considered for customizing the $\mathrm{P} \& \mathrm{O}$ MPPT algorithm parameters in order to avoid the instability of the algorithm.

Chen et al. [53] have proposed the biological swam chasing PV MPPT algorithm to improve the MPPT performance. On comparing with a typical $\mathrm{P} \& \mathrm{O}$ algorithm the efficiency of the MPPT is improved to $12.19 \%$ in the transient state. Wang et al. [54] have proposed the PV model based mathematical models of photovoltaic array on the basis of P\&O method. In this the characteristics of photovoltaic arrays are analyzed. Razali and Rahim [55] present the experimental works on a standalone solar system with P\&O MPPT algorithm.

Guo et al. [56] have analyzed the equivalent model of PV cells based on Real Time Digital Simulation (RTDS) and study the output characteristics of PV cells. In this control of 3-phase PWM inverter controls the output active and reactive power with maintaining of $\mathrm{DC}$ bus voltage to a limited reference value.

3.3. Artificial Neural Network Based MPPT Techniques. In this technique, a multilayered feedback neural network with back propagation trained network is used. A two-stage offline trained Artificial Neural Network based MPPT with two cascaded ANNs estimates the temperature and irradiance levels from the PV array voltage and current signals. This technique gives the better performance even under rapidly changing environmental conditions for both steady and transient instants with reducing the training set usually; a three-layer RBF $\mathrm{NN}$ is adopted for implementing the MPPT. Ciabattoni et al. [82] have presented the home energy management system using neural network which monitors the home loads, forecasts photovoltaic production and home consumption, and influences the users on their energy choice. Jiang et al. [83] have implemented the two-stage MPPT to improve nonuniform irradiance on the PV modules. In this solar array model, a blocking diode is connected in series to PV string to prevent reverse current flow from load; a bypass diode is also used to improve the power capture and prevent hotspots.

Lee et al. [84] have presented the ANN based MPPT 2-stage method for maximum power point; this algorithm independent of time dependency and trade property due to this MPP can be tracked without time increment through PV characteristics changes. Sheraz and Abido [85] overcome the problem of nonlinear characteristics of PV array with rapidly changing irradiation and temperature using Differential Evolution (DE) and ANN along with conventional MPPT to track the maximum power point. Phan et al. [86] have implemented the ANN based MPPT and Incremental Conductance method for searching maximum power point based using feedback voltage and current without PV array characteristics. This method solves the time dependence and trade-off as tracking time is very fast. Experimental valuation is carried out using dSpace 1104.

Xu et al. [87] have presented a new ANN based MPPT algorithm by using the traditional Incremental Conductance using sensors to get better performance. Compared with the 




FIgURE 8: ANN based MPPT.

Incremental Conductance and the $\mathrm{P} \& \mathrm{O}$ controller, it is much faster to the sudden change of the weather combinations. To evaluate the effectiveness of the training network, the mean square error is introduced to give the better performance and accuracy of the network. Jie and Ziran [88] have implemented the 2-level neural network-genetic algorithm to estimate battery power influencing factors as light intensity, temperature, and battery junction temperature. Maximum power point of photovoltaic system can be controlled online with the use of transform technology of semiconductor memory.

Durgadevi et al. [89] studied $V-I$ and $P-V$ characteristics of PV cell with ANFIS model and empirical model for various temperature and illumination ageing effects of equipment. In this, when compared to empirical model, ANFIS model gives better results. Elobaid et al. [90] have proposed the two-stage Artificial Neural Network based MPPT to estimate the temperature and irradiance levels from array voltage and current signals in order to determine the optimum peak operating point. This technique gives the better performance even under rapidly changing environmental conditions for both steady and transient instants. Jiang et al. [91] have proposed the two-diode PV array model to improve the accuracy under low irradiance and to reduce computational time and irradiance.

Zhang et al. [92] have presented the recurrent neural network model trained by a Particle Swarm Optimization (PSO) for solar radiation monitoring and controlling and to predict accurately the solar radiation of standalone systems and of hybrid power systems. Chiu et al. [93] have presented the ANN based for piecewise line segments (PLS) to approximate the maximum power point locus. It is of high speed, lowcomplexity MPPT technique. In this, a separate high speed voltage is applied to regulate the PV panel output voltage and to follow the emulated MPP locus (EML), a good response due to sudden changes of irradiance levels, and helps to improve the tracking efficiency. This method is simple and achieves the good static and dynamic tracking.
Yamauchi [94] has proposed the MPPT using a limited general regression neural network (LGRNN) for testing of two series connected solar panels if one of the panels is under shading condition. The LGRNN is used for learning each panel output at instances with a limited memory capacity. Anitha and Prabha [95] have presented Artificial Neural Network based MPPT controller for the PV system in order to overcome the drawback of slow, wrong tracking and to operate it at maximum point and reduce oscillations during rapidly changing weather conditions. In this and with the help of boost converter, inverters are used to provide maximum output voltage to the load. Here back propagation feed forward trained networks are introduced to overcome the nonlinearity of PV arrays.

Yong et al. [96] have presented the ANN based MPPT control to track the MPP at different weather and irradiance. This network is used to overcome slow tracking speed, more output oscillations, and power oscillations. Ramaprabha et al. [97] have discussed the 3-layered ANN with back propagation algorithm based MPPT for boost converter for standalone PV system to minimize the long term system losses and to increase the conversion efficiency. Even under variable temperature it gives optimum output voltage. Multilayered feed forward neural network based MPPT algorithm flow chart is shown in Figure 8.

3.4. Fuzzy Logic Controller Based MPPT Techniques. Fuzzy logic control is a convenient way to map an input space to output space. Fuzzy logic uses fuzzy set theory, in which a variable is a member of one or more sets, with a specified degree of membership. A fuzzy logic controller basically includes three blocks named fuzzification, inference, and defuzzification. Afghoul et al. [98] have implemented the hybrid adaptive neurofuzzy inference system to find operating point near the MPP. Sreekumar and Benny [99] have implemented fuzzy logic to obtain maximum MPP operating voltage fluctuations using Mamdani method. This 
method tracks the maximum power rapidly compared to conventional algorithm. Adly et al. [33] have compared the Incremental Conductance and fuzzy MPPT techniques for the PV model under fast changing environmental conditions. Here DC-DC converter is used as isolation stage for a load connected PV module. Mellit et al. [100] predicted the daily total solar radiation data from sunshine duration and ambient temperature based on ANFIS model. Here mean relative error (MRE) produces very accurate estimation between the actual and predicted data without exceeding of $1 \%$. Hossain et al. [101] have proposed the intelligent method for maximum power point tracking of a PV system under variable temperature and insolation conditions. In order to overcome nonlinearity characteristics of PV cell fuzzy logic control implemented, the duty cycle for the converter is calculated based on fuzzy logic control algorithm. Nabulsi et al. [102] have made a comparison between two controllers as Hill Climbing, two input fuzzy controllers, and single input fuzzy controller for tracking maximum power point. The basic idea behind these MPPT techniques is to find the optimum duty cycle that results in maximum power delivered from the PV panel through DC/DC converter to the load. In this Hill Climbing method controls of the operating point of PV array that oscillates around the MPP with causing of power loss, fuzzy with 2 inputs, requires more calculation with $N * N$ rules in addition to two inputs and output gains but single input fuzzy controller is implemented with least settling time, acceptable oscillations around MPP. Hadjammar and Bouchafaa [103] have introduced the fuzzy logic based MPPT to extract the maximum power and to feed a three-level Neural Point Clamped (NPC) VSI from the photovoltaic system, where this gives the larger number of levels of output waveforms with lower $d V / d T$, less harmonic distortion, and lower switching frequencies. In this multilevel inverter with grid connected PV system using MPPT extracts maximum power, controls active and regulate the reactive power injected into the grid.

Mellit and Kalogirou [104] have presented ANFIS modeling of photovoltaic power supply systems under variable climatic conditions, variable radiation, temperature, and humidity. Wang et al. [105] have presented the PV plug in hybrid electric vehicles power supply system as the energy storage by replacing the battery and treating as power source for the intelligent community by using of hierarchical fuzzy control with reducing the number of fuzzy rules. Here HFC maintains the output power and reliability of grid from load fluctuations. Chin et al. [106] have discussed the optimization of PV system under partially shaded conditions with the $\mathrm{P} \& \mathrm{O}$ algorithm to overcome a low accuracy fuzzy logic algorithm which has been implemented to obtain faster MPP control and more stable output power under transient and steady state conditions. The tracking and settling time with FMPPT is very low compared to $\mathrm{P} \& \mathrm{O}$ algorithm and also to conventional MPPT. Thus, FMPPT gives better efficiency. Iqbal et al. [107] have presented the maximum power with fast response in the available solar irradiance and temperature. Here MPPT are used for the voltage adjustments of PV modules by changing duty ratio of boost converter which is used for calculation of solar irradiance and temperature.
ANFIS controller outputs the crisp value of maximum power, where this power is calculated by the multiplication algorithm of sensed voltage and current; the error in power is processed through PI controller by giving its output to the PWM which blocks DC-DC converter to adjust the operating PV module.

Kulaksiz and Aydoğdu [108] have presented ANFIS controller for a PV system, in order to control DC-DC buck converter by providing the duty cycle for the DC-DC buck converter. Cigdem et al. [109] have presented the sliding mode control to overcome the drawbacks of long convergence process in case of uncertainties and disturbances. In this it tunes ANN and FNN algorithms online. Chiu and Ouyang [110] have developed a Sugeno fuzzy MPPT method for PV system. Here maximum power voltage-based control (MPV) direct maximum power (DMP) are used to control the output PV voltage to the reference PV voltage Vref from MPP decision maker and to control the power slope. Subiyanto et al. [111] proposed fuzzy logic controller to overcome the draw backs of nonlinearity of PV output due to changes in temperature and irradiation.

\subsection{Particle Swarm Optimization Based MPPT Algorithm for} $P V$ System. This algorithm is used to reduce the steady state oscillation to practically zero once the maximum power point is located. Furthermore, it has ability to track the MPP for the extreme environmental conditions like large fluctuations of insolation and partial shading condition. The MPP tracker based on Particle Swarm Optimization for photovoltaic module arrays is capable of tracking global MPPs of multipeak characteristic curves where the fixed values were adopted for weighing within the algorithm, the tracking performance lacked robustness, causing low success rates when tracking the global MPPs. Though the MPPs were tracked successfully, the dynamic response speed is low. The IPSO based MPPT controller algorithm for various environmental conditions like fully shaded conditions and partially shaded conditions to find new global MPP with reinitialization of particles can be observed [112]. The IPSO based flow chart algorithm is shown in Figure 9.

The PSO has simple structure, easy implementation, and fast computation capability. It is able to locate the MPP for any type of $P-V$ curve regardless of environmental variations and also to track the PV system as the search space of the PSO reduced and the time required for the convergence can be greatly reduced. Interestingly the searching speed through adaptive learning factors and inertia weight were not satisfied by the researchers [113-116] because of the linearity in line with increasing iteration numbers which were adopted for the weighing of the PSO formulas. The IPSO based MPPT can be used to predict the $I-V$ and $P-V$ characteristics curves during partial shading condition also to evolve and ratify the photovoltaic system design encompassing the power converter and MPPT controller [117-119]. Miyatake et al. [120] presented the power loss due to partial sharing and minimization by dividing the PV system into number of small arrays which enables its control by its own converter for each array. If the number of modules increases, then the characteristics are under uneven insolation; if one module is fully illuminated and the other one is partially shaded, then 




FIGURE 9: Flowchart of IPSO based MPPT algorithm.

current generated by the first one is more than the second one. During this excess, current will flow through bypass diode with existing of two MPPs.

\section{MPPT Controller with DC-DC Converters}

Chin et al. [57] presented a DC-DC converter to transfer maximum power from the solar PV module to the load. This is achieved by module by changing the duty cycle of a converter so that the load impedance is varied and matched at the point of peak power with the source. Spiazzi et al. [58] have discussed ripple correlation control (RCC) technique on correlation existing between PV panel power, voltage, and current ripples and can exploit the AC signals caused by switching action of the converter. It is mainly used to equilibrium point in case of nonsinusoidal and to analyze the simple effects of reactive parasitic components like panel shunts capacitance and series inductance. Finally it is observed that the combined effects of reactive parasitic components can lead to the unacceptable errors in the MPP tracking capability where a high frequency DC-DC converter is used.

Huusari and Suntio [59] have proposed the distributed maximum power point tracking in order to overcome the effect of shading used to reduce the output power. Each PV module is connected by a DC-DC converter to extract maximum power where its output is connected to the grid connected inverter. They also discussed the terminal constraints, topological constraints, and dynamic constraints to get maximum output voltage. Luo and Han [60] have studied the MPPT with MCU control system in a grid connected photovoltaic generation system by introducing DC-DC conversion techniques. Patel and Shireen [61] give an analysis of the PV module characteristics and determination of short-circuit current to get converging maximum power point tracking control. It is observed by connecting the DCDC converter between the PV source and the load with pulse width modulation control of the converter. In this, the short-circuit current, open circuit voltage, and load voltage at MPP are determined. Here the boost converter is turned to ensure the operation of $\mathrm{PV}$ array at its maximum power point 
regardless of atmospheric conditions and load variations. Trejos et al. [62] have presented the DC link voltage oscillation compensations in grid connected PV systems based on three different DC/DC converters such as Cuk converters, SEPIC converters, and Zeta converters. These high order converters are suitable for reducing the current ripple injected in the PV array and load.

Koutroulis et al. [63] have proposed low power consumption MPPT for battery charging consisting of a high efficiency DC/DC buck type converter. A microcontroller based unit is used to control the $\mathrm{DC} / \mathrm{DC}$ converter directly from the PV array output power. Liang et al. [64] have introduced a switching capacitor buck-boost DC/DC converter to process the energy operated by PV module. Cupertino et al. [65] have presented the control in a maximum power tracker boost converter for a grid connected photovoltaic system using two topologies. This active power injected in the grid is close to generated value besides the control of the inverter which reduces the harmonic distortion. Pan et al. [66] have proposed the MPPT strategy to charge the photovoltaic system. This charging needs PV array, DC/DC controller, and battery. As the output characteristics of PV array vary with the change in solar radiation, ambient temperature due to this constant voltage and constant current are not suitable for PV charging system. Here DC/DC converter is used to track the output current and adjusts the perturbation step to achieve fast accurate tracking. In the charging management, an optimal charging strategy integrates MPPT charging with variable intermittent current charging to increase the battery's charging acceptance and level of state of charge.

\section{Reduction of Harmonics}

Jain and Agarwal [133] proposed that the voltage obtained from a PV system is low, and a DC-DC boost converter is necessary to generate a regulated higher DC voltage. A voltage source inverter interfaces the PV module with the standalone application to provide an AC output voltage without transformer. For lower generating systems, the conventional pulse width modulated inverter is used because of simple and easy control mechanism [134]. PWM inverters usually involve fast switching of semiconductor switches due to which high frequency noise gets generated. Also all PWM methods inherently generate harmonics that originate from the high $d V / d t$ and $d I / d t$ semiconductor switching transients [135]. These drawbacks result in distorted output, and traditionally passive filters have been used to remove the harmonics from the line current. These filters improve the power factor of the system $[136,137]$, but the passive filters have many drawbacks such as tuning problems and series and parallel resonance [138]. Typical shunt and series active filter topologies along with passive filters are proposed to provide high quality power for a PV system [139]. The passive filter design is carried out with LC, LCL, and LLCC filter topologies. The work evaluates the total harmonic distortion using each passive and a comparison is done with respect to power quality improvement.

Khoucha et al. [140] stated that the main objective of this is to minimize the inductor size, capacitor current/voltage ripples, and harmonic content through the special structured interleaved boost converter to increase the converter efficiency. A study of prototype hardware also took place with DSP based controlled PV emulator, to make operating point always at maximum power point. Nousiainen and Suntio [141] presented the dynamic analysis of the converter with the 1-phase grid connected inverter applications by considering the dynamic properties of the PV generator. In this, the converter gives the automatic high power decoupling that eliminates the ripple at twice the grid frequency at the output. Akhtar and Ikkurti [142] present the controller design for maximum power extraction from photovoltaic system using phase modulated full bridge topology boost converter. In order to boost up the PV panel voltage pulse width modulation boost converters are used. LC filter is connected to the output in order to filter the harmonic components. Mummadi et al. [143] described the performance of PV system which mainly depends on type of power converter, tracking methodology, and nature of filters employed. Here, authors also explained the buck-boost topologies for the MPPT with connection of the capacitor filter, single stage LC filter, and the multistage filters to minimize the electromagnetic noise in the pulsating source current waveform. Liang et al. [144] have introduced a switching capacitor buck-boost DC/DC converter to process the small portion of energy operated by PV module to perform MPPT control. This converter is in parallel with the unregulated switching capacitor resonant converter to step up the voltage. To reduce the high frequency current ripple filter capacitors are used. The ZVS turn-on and ZCS turn-off of all switches in switching capacitor converter are obtained with the help of small auxiliary inductance (Laux).

Tummuru et al. [145] have presented a fourth-order front end boost converter topology with single sensor MPPT for PV applications. It provides higher voltage gains with less duty ratio, less voltage stresses on switching devices, and the converter voltage reverse recovery problem. To overcome this, the converter is operated at continuous current mode (CCM), and also fourth-order coupled inverter boost converter is introduced with MPPT algorithm having less duty cycle. Brando et al. [146] have proposed the sensor less control of $\mathrm{H}$ bridge multilevel converter for MPPT in grid connected PV systems to deliver maximum power. Boonmee and Kumsuwan [147] overcome the drawbacks like complexity, sensor requirement, speeds of convergence, cost range of effectiveness, and implementation hardware.

He et al. [148] calculated the time due to control delay to overcome the fast parallel computation and learning capability of RBF Neural Network which is used. The control signal for the hybrid cascaded multilevel inverter with the modulation methods in multilevel inverters can be classified according to switching frequency. Methods that work with high switching frequencies have many commutations for the power semiconductors in one period of the fundamental output voltage. A very popular method in industrial applications is the classic carrier-based sinusoidal PWM (SPWM) that uses the phase-shifting technique to reduce the harmonics in the load voltage; another interesting alternative is the SVM strategy, which has been used in three-level inverters. 
Methods that work with low switching frequencies generally perform one or two commutations of the power semiconductors during one cycle of the output voltages, generating a staircase waveform. Representatives of this family are the multilevel selective harmonic elimination and the spacevector control (SVC) [149-151].

\section{Usage of Battery and Inverter Systems}

Inverter is a power electronic device that converts DC to AC. Inverter is essential for a photovoltaic system designed to be as a grid tied or off grid.

6.1. Grid Tied Inverters. These solar panels are usually wired in series to produce very high voltages, usually between 200 and 600 volts using $\mathrm{Cu}$ wire but nowadays it became a significant expense due to rise in the price of copper. Grid tied inverters are designed to take as input the high DC voltages that are common in the systems. They are also designed such that if the grid goes down for any reason, the will turn off the supply from the solar panels at the utility because the side should not get shocked.

6.2. Standalone Inverters. They are designed for off grid systems. They are designed to receive power both from the solar panels and from the battery backup system. Off grid inverters usually have a number of features designed to optimize the performance of your battery system. In addition, they are designed to work with lower voltages given that the batteries are usually operating between 12 and 48 volts.

6.3. Grid Tied Inverters with Battery Backup. They are used in hybrid systems which are tied but also have battery banks as backup when the grids ever go down. They tend to have features which are found in both grid tied and off the grid inverters [152]. The PV system architecture can be categorized into three basic classes: central inverter, string or multistring inverter, and module integrated converter. Although the central inverter can operate at high efficiency with only one $\mathrm{DC} / \mathrm{AC}$ power conversion stage, this structure has some disadvantages such that each module may not operate at its maximum power point which results in less energy harvested; additional losses are introduced by string diodes and junction box and single point of failure and mismatch of each string of PV panel affects the PV array efficiency greatly [153-156].

The PV stations make use of smart PV inverters as proposed by Seal [157]. This allows coordinating the regulated voltage on distribution system $[158,159]$. Based on knowledge from shunt capacitor placement and distributed generated placement, better voltage regulation can be attained. When the energy storage is placed and used to provide voltage regulation, this places a constraint on when it can be charged and discharged. This constraint must be taken into account when scheduling the energy storage. Basically a highly efficient reliable modular battery storage system (HERMES) is an ongoing research to develop for a flexible energy storage system [160]. Various methods have been presented to provide continuous power supply to consumers such as uninterruptible power supply and battery system.
Cavallaro et al. [161] have discussed the use of photovoltaic system for smart photovoltaic UPS system suitable for domestic applications, the application of utility interactive photovoltaic power generation system UPS [162]. Multilevel inverter topologies for standalone photovoltaic systems with their suitabilities for standalone applications were discussed [164]. A single phase grid connected system for photovoltaic modules has DC-DC or DC-AC converter to avoid DC current injection problem by Kang et al. [164]. These are of power electronic configurations, single stage and double stage conversion. In the double stage conversion for a PV system, the first stage is a DC-DC converter and the second stage is a DC-AC inverter. The function of DC-DC converter is to facilitate the maximum power point tracking of the PV array and to produce the appropriate DC voltage for the DC-AC inverter. The function of inverter is to generate three-phase sinusoidal voltages or currents to transfer the power to the grid in a connected solar PV system or the load in standalone system $[165,166]$.

The single stage is having higher efficiency; however, most complex method is required. The currents for the industry for high power applications in three-phase and single stage PV energy systems by using a voltage source conversion were discussed [168]. One of the major concerns of solar and wind energy systems is their unpredictable and fluctuating nature. Grid connected renewable energy systems with battery energy storage can overcome this concern. This is also can increase the flexibility of power system control and raise the overall availability of the system. Usually, a converter is required to control the charging and discharging of the battery storage system required for DC-AC power conversion; thus, a three-phase PV system connected to battery storage will require two converters [168].

Battery energy storage systems can be built with low or high charging systems. High voltage batteries consist of many batteries connected in series. The drawback is that the string fails if one battery cell's impedance becomes highly ohmic due to a fault. Depending on the batteries technology, a battery monitoring system and optionally a battery balancing system are necessary to operate the battery reliably [169]. As exceptions to these Zebra batteries, if one cell fails, the Zebra battery becomes of low ohmic and can conduct the full current [170].

Low voltage batteries require a voltage boost for the medium voltage grid connection, which is achieved by special power electronic topologies [171, 172]. The application of grid support with EV batteries requires the combination of both. High load functions and continuous operation over many years are challenging requirements from a reliability and life time perspective. Therefore, the number of allowed cycles over time has a remarkable influence on cost and life time of such a system [173-175].

\section{Issues/Challenges of PV System}

Although solar energy is an infinite energy source derived from the environment, its supply is intermittent; yet its availability is less than predictable and is outside human control as compared to conventional power plants. Continuous research 
and development are going on to meet the challenges pertaining to solar power generation, namely, high initial cost, variability, requirement of space for PV panel installation, and less efficient energy conversion to name a few.

Solar power is not always available where and when needed. Unlike conventional sources of electric power, solar resources are not dispatchable; the power output cannot be controlled. Daily and seasonal effects and limited predictability result in intermittent generation. This poses many challenges for the grid integration. Some of these challenges are given below as [176-182].

7.1. Intermittent Generation. The intermittent nature of solar resource and limited dispatchability require grid operators to maintain additional spinning reserves.

Accurate hourly and subhourly solar generation forecasting are required to allow for unit commitment and spinning reserves, scheduling, and dispatch.

7.2. Transmission System Issue. Large scale solar plants (100 MW and above) may be located in places distant from any existing transmission lines. Planning for transmission expansion to support increasing level of solar generation in dispersed areas is essential to the growth of the solar power sector. Planning and system studies are required to determine seasonal requirements for upregulation, downregulation, and ramping capacities. Long term resource adequacy issues also need to be addressed. The interconnection protocols and standards may need to be modified to address greater level of power factor control and low voltage ride to mitigate any transient stability issues.

7.3. Distribution System Issues. The increasing penetration of institutional and residential solar generation imposes challenges on the existing distribution infrastructure. Grid operators are facing shifts in peak demand, load pattern resulting in a scenario wherein generators are being called upon to ramp up their output more than before and for which they may have not been designed [176]. New control strategies to enhance the distribution automation, microgrid capabilities, voltage, and volt-ampere reactive (VAR) power managements are to be improved. Integration of renewable energy into the smart grid with innovative energy storage is the key to smooth this variability which partially alleviates some of these challenges and achieves greater reliability in delivery. Future energy sustainability depends heavily on how the renewable energy problem is addressed in the next few decades.

7.4. Integrating Energy Storage. Although an excellent style in Electric Energy storage is a well-established practice, its use in PV systems is usually for standalone systems. As the percentage share of PV generated energy is increasing in the total energy basket, it is necessary to integrate energy storage with PV-grid tied systems. The integration will add value to utilities and customers through improved reliability enhanced power supply and economic delivery of electricity. The applications most likely to benefit from PV storage and integrating it with grid are peak shaving, load shifting, microgrids, outage protection, and demand responds [179]. Designing optimized systems based on existing storage technologies will require knowledge of the application and modeling tools to accurately simulate the operating conditions and cost effects of a PV storage system used in that application.

The energy storage can keep the plant output within required range by drawing power from the storage device when cloud moves in and cuts off some of the plant output after it passes. This can be done in the case of inverters for the startup or for the defocusing trackers. The power electronics and control strategies are required for ensuring all parts of grid connected distribution sources and storage system work. Energy storage is becoming more appealing in smart grids. It can be used for frequency regulation, voltage regulation, capacity firming, and islanding operation in microgrids apart from ramping.

(i) Peak Saving. PV system requires providing all the required power above with a threshold value. If the PV system is not available then the required adequate energy is supplied or provided by the energy storage system to fill the energy gap. Thus reliability of PV storage is a key element. To implement peak saving, the system controller must be able to dispatch power from the storage system if PV system is unavailable to meet the load.

(ii) Load Shifting. Many peak loads occur late in the day, after the peak for PV generation has passed. Storage can be combined with PV system to reduce demand for utility power during late-day, higher rate times by charging a storage system with PV generated energy early in the day, or to support a load later in the day.

(iii) Demand Response. While both residential and commercial PV storage systems have the inherent capability to manage demand response requirements, control systems are capable of reacting to demand response to be developed.

(iv) Outage Protection. Smart grids insulate end users from loss of power or failure of one part of the energy network. This is ensured by intelligent distribution topologies for the flow of changes in real time to meet the goals of better delivery, cheap generation, cheap distribution, and anticipating, detecting, and responding to system problems and automatically avoiding or mitigating the various kinds of power disruptions.

(v) Grid Power Quality Control. Power quality ensures constant voltage, phase angle adjustment, and removal of extraneous harmonic content from the electric grid. The common problem is voltage sag in which the UPS can supply the energy needed to return the voltage to the desired level. UPS functions can be added to PV storage system in the power conditioning system by designing it to handle high power applications including necessary control functions.

\section{Advantages and Disadvantages of Solar PV System}

\subsection{Advantages}

(i) Although the feed-in tariff has changed quite a bit since it was introduced, solar PV systems are still 
a great investment because they substantially lower your electric bill [183].

(ii) The price of solar panels has gone down by 45 percent or more, which makes the entire system much more affordable [183].

(iii) Solar PV systems operate differently than solar thermal ones. Solar PV system actually generates free electricity while solar thermal systems heat up your water [183].

(iv) Solar photovoltaic systems require daylight and so will work in days when the sun is not shining. All you need is light to create energy, so although the effectiveness of the solar PV array will be less when the sun is covered by clouds, it will still generate some electricity [183].

(v) Utilizing solar power helps lower your electric bills because you are generating some of the electricity you use. Some systems can generate as much as 40 percent of the electricity you use on an annual basis [183].

(vi) There is very little maintenance involved in owning a solar PV system. Just make sure that you purchase the system from a company with a solid reputation so that you know you are buying quality panels and a good aftercare service [183].

(vii) The feed-in tariff is designed to increase the amount of solar power being utilized in the UK, but it also makes the installation of solar PV systems look even more attractive to home and business owners [183].

(viii) By using green energy instead of fossil fuels, you are doing what you can to protect the environment. Our world's fossil fuel reserves are rapidly decreasing, so we will have to find alternative fuels soon. Solar $\mathrm{PV}$ panels provide a green way to produce electricity [183].

\subsection{Disadvantages}

(i) Solar PV panels are more expensive than panels designed for solar thermal energy. However, they do a lot more for your home or business than solar thermal panels do, and there are some incentives and grants to help pay for them [183].

(ii) You need an adequate roof space to display your solar $\mathrm{PV}$ panels. The larger the panel covering the more the electricity generated [183].

(iii) Solar PV panels may not be a viable green energy option for your home or business if you have a predominantly north or east facing roof or if tall buildings and/or trees place your roof in the shade during the day [183].

\section{Conclusion}

The use of solar energy is essential for providing solutions to the environmental problems and also energy demand. The vast development to improve the efficiency by the MPPT algorithms encouraged the domestic generation of power using solar panels. The available MPPT techniques based on the number of control variables involved, types of control strategies, circuitry, and applications are possibly useful for selecting an MPPT technique for a particular application for grid tied or standalone mode of operations. This review has included many recent hybrid MPPT techniques along with their benefits for mismatched conditions such as partial shading, nonuniformity of PV panel temperatures, and dust effects.

It is observed that Perturbation and Observation and Incremental Conductance methods are simple and used by many researches, but they have the slow tracking and low utilization efficiency. To overcome the drawbacks, fuzzy and neural network techniques are used in the present days by which the efficiency is increased. To boost up the voltage various DC-DC converters are used along with battery storage systems in order to store the excessive energy from solar PV panel. The DC link voltage oscillations in the grid connected PV system can be obtained by using Cuk converters, SEPIC converters, and Zeta converters with reducing current ripple injected in the PV array and load. The harmonic content is reduced from the output of DC-DC converters using the filter circuits. The passive filters as LC, LCL, and LLCC are used for harmonic distortion as well as to improve the power quality. Filter capacitors are used to reduce high frequency current ripple.

This DC is again fed to the inverter for converting the DC to AC with various PWM techniques. These PWM inverter techniques yield the better $\mathrm{AC}$ outputs which are used to connect the grid interconnections and standalone AC loads. Multilevel inverters with sinusoidal PWM and SVM are used to reduce the harmonics in the load voltage even in low switching frequency. Grid tied inverters with battery backup are preferred in hybrid systems for backup even if the grid goes down for both grid tied and off grid systems.

\section{Future Scope}

The work that had been carried out by the researchers, the designing of MPPT controller, should be extended by tracking larger number of input parameters which are varying with respect to the time such as parameters variations of the system. In order to get accurate MPPT point, the recent mathematical algorithms such as $Z$-infinity algorithms should be implemented. The work that has been carried out to the DC-DC converter is limited only by considering high switching frequency.

But the output voltage THD values are not improved much so that the research should be carried out in this area; a filter circuits configuration should be improved. For the inverter circuits, the grid tied inverters are having the problem that if the grid fails, the customer will not get any supply even though there is power generation from the PV system. This should be considered as a serious problem and the research should be carried out in this area.

\section{Competing Interests}

The authors declare that they have no competing interests. 


\section{Acknowledgments}

The funding support given by SERB, Department of Science and Technology (DST), Government of India, with vides SERB order no. SERB/ET-069/2013 for the solar based project is acknowledged.

\section{References}

[1] A. Mathew and A. Immanuel Selvakumar, "MPPT based standalone water pumping system," in Proceedings of the IEEE International Conference on Computer, Communication and Electrical Technology (ICCCET '11), pp. 455-460, Tamil Nadu, India, March 2011.

[2] R. Faranda and S. Leva, "Energy comparison of MPPT techniques for PV systems," WSEAS Transactions on Power Systems, vol. 3, no. 6, pp. 446-455, 2008.

[3] C. Liu, B. Wu, and R. Cheung, "Advanced algorithm for MPPT control of photovoltaic systems," in Proceedings of the Canadian Solar Buildings Conference, Montreal, Canada, 2004.

[4] F. Liu, Y. Kang, Z. Yu, and S. Duan, "Comparison of P\&O and hill climbing MPPT methods for grid-connected PV converter," in Proceedings of the 3 rd IEEE Conference on Industrial Electronics and Applications (ICIEA '08), pp. 804-807, Singapore, June 2008.

[5] A. Mellit and S. A. Kalogirou, "Artificial intelligence techniques for photovoltaic applications: a review," Progress in Energy and Combustion Science, vol. 34, no. 5, pp. 574-632, 2008.

[6] S. Ait Cheikh, C. Labres, G. F. Tchoketch Kebir, and A. Zerguerras, "Maximum power point tracking using a fuzzy logic control scheme," Revue des Energies Renouvelables, vol. 10, pp. 387-395, 2007.

[7] A. Saadi and A. Moussi, "Neural network use in the MPPT of photovoltaic pumping system," Revue des Energies Renouvelables, pp. 39-45, 2003.

[8] M. Yue and X. Wang, "A revised incremental conductance MPPT algorithm for solar PV generation systems," http://arxiv .org/abs/1405.4890.

[9] K. H. Hussein, I. Muta, T. Hoshino, and M. Osakada, "Maximum photovoltaic power tracking: an algorithm for rapidly changing atmospheric conditions," IEE Proceedings: Generation, Transmission and Distribution, vol. 142, no. 1, pp. 59-64, 1995.

[10] T.-Y. Kim, H.-G. Ahn, S.-K. Park, and Y.-K. Lee, "A novel maximum power point tracking control for photovoltaic power system under rapidly changing solar radiation," in Proceedings of the IEEE International Symposium on Industrial Electronics (ISIE '01), pp. 1011-1014, IEEE, Pusan, South Korea, June 2001.

[11] Y.-C. Kuo, T.-J. Liang, and J.-F. Chen, "Novel maximum-powerpoint-tracking controller for photovoltaic energy conversion system," IEEE Transactions on Industrial Electronics, vol. 48, no. 3, pp. 594-601, 2001.

[12] W. Wu, N. Pongratananukul, W. Qiu, K. Rustom, T. Kasparis, and I. Batarseh, "DSP-based multiple peak power tracking for expandable power system," in Proceedings of the 18th Annual IEEE Applied Power Electronics Conference and Exposition (APEC '03), pp. 525-530, IEEE, Miami Beach, Fla, USA, February 2003.

[13] H. Koizumi and K. Kurokawa, "A novel maximum power point tracking method for PV module integrated converter," in Proceedings of the IEEE 36th Power Electronics Specialists Conference, pp. 2081-2086, IEEE, Recife, Brazil, June 2005.
[14] K. Harada and G. Zhao, "Controlled power interface between solar cells and AC source," IEEE Transactions on Power Electronics, vol. 8, no. 4, pp. 654-662, 1993.

[15] K. Irisawa, T. Saito, I. Takano, and Y. Sawada, "Maximum power point tracking control of photovoltaic generation system under non-uniform isolation by means of monitoring cells," in Proceedings of the 28th IEEE Conference on Photovoltaic Specialists, pp. 1707-1710, September 2000.

[16] K. Kobayashi, I. Takano, and Y. Sawada, "A study on a two stage maximum power point tracking control of a photovoltaic system under partially shaded insolation conditions," in Proceedings of the IEEE Power Engineering Society General Meeting, vol. 4, pp. 2612-2617, Toronto, Canada, July 2003.

[17] K. S. Tey and S. Mekhilef, "Modified incremental conductance MPPT algorithm to mitigate inaccurate responses under fastchanging solar irradiation level," Solar Energy, vol. 101, pp. 333342, 2014.

[18] Q. Mei, M. Shan, L. Liu, and J. M. Guerrero, "A novel improved variable step-size incremental-resistance MPPT method for PV systems," IEEE Transactions on Industrial Electronics, vol. 58, no. 6, pp. 2427-2434, 2011.

[19] F. Liu, S. Duan, F. Liu, B. Liu, and Y. Kang, "A variable step size INC MPPT method for PV systems," IEEE Transactions on Industrial Electronics, vol. 55, no. 7, pp. 2622-2628, 2008.

[20] A. Safari and S. Mekhilef, "Simulation and hardware implementation of incremental conductance MPPT with direct control method using cuk converter," IEEE Transactions on Industrial Electronics, vol. 58, no. 4, pp. 1154-1161, 2011.

[21] Y. Zhou, F. Liu, J. Yin, and S. Duan, "Study on realizing MPPT by improved incremental conductance method with variable stepsize," in Proceedings of the 3rd IEEE Conference on Industrial Electronics and Applications, pp. 547-550, IEEE, Singapore, June 2008.

[22] B.-C. Chen and C.-L. Lin, "Implementation of maximumpower-point-tracker for photovoltaic arrays," in Proceedings of the 6th IEEE Conference on Industrial Electronics and Applications (ICIEA '11), pp. 1621-1626, IEEE, Beijing, China, June 2011.

[23] N. Onat, "Recent developments in maximum power point tracking technologies for photovoltaic systems," International Journal of Photoenergy, vol. 2010, Article ID 245316, 11 pages, 2010.

[24] D. P. Hohm and M. E. Ropp, "Comparative study of maximum power point tracking algorithms," Progress in Photovoltaics: Research and Applications, vol. 11, no. 1, pp. 47-62, 2003.

[25] T. Esram and P. L. Chapman, "Comparison of photovoltaic array maximum power point tracking techniques," IEEE Transactions on Energy Conversion, vol. 22, no. 2, pp. 439-449, 2007.

[26] E. Román, R. Alonso, P. Ibañez, S. Elorduizapatarietxe, and D. Goitia, "Intelligent PV module for grid-connected PV systems," IEEE Transactions on Industrial Electronics, vol. 53, no. 4, pp. 1066-1073, 2006.

[27] S. M. R. Kazmi, H. Goto, O. Ichinokura, and H.-J. Guo, "An improved and very efficient MPPT controller for PV systems subjected to rapidly varying atmospheric conditions and partial shading," in Proceedings of the Australasian Universities Power Engineering Conference (AUPEC '09), pp. 1-6, IEEE, Adelaide, Australia, September 2009.

[28] B. Liu, S. Duan, F. Liu, and P. Xu, "Analysis and improvement of maximum power point tracking algorithm based on incremental conductance method for photovoltaic array," in Proceedings of the 7th International Conference on Power Electronics and 
Drive Systems (PEDS '07), pp. 637-641, Bangkok, Thailand, November 2007.

[29] Y. Yusof, S. H. Sayuti, M. Abdul Latif, and M. Z. C. Wanik, "Modeling and simulation of maximum power point tracker for photovoltaic system," in Proceedings of the National Power and Energy Conference (PECon '04), pp. 88-93, Kuala Lumpur, Malaysia, November 2004.

[30] A. F. Murtaza, H. A. Sher, M. Chiaberge, D. Boero, M. De Giuseppe, and K. E. Addoweesh, "Comparative analysis of maximum power point tracking techniques for PV applications," in Proceedings of the 16th International Multi Topic Conference (INMIC '13), pp. 83-88, IEEE, Lahore, Pakistan, December 2013.

[31] F. Keyrouz and S. Georges, "Efficient multidimensional Maximum Power Point Tracking using Bayesian fusion," in Proceedings of the 2nd International Conference on Electric Power and Energy Conversion Systems (EPECS '11), pp. 1-5, Sharjah, United Arab Emirates, November 2011.

[32] P. Wolfs and Q. Li, "A current-sensor-free incremental conductance single cell MPPT for high performance vehicle solar arrays," in Proceedings of the 37th IEEE Power Electronics Specialists Conference (PESC '06), pp. 1-7, IEEE, Jeju, South Korea, June 2006.

[33] M. Adly, M. Ibrahim, and H. El Sherif, "Comparative study of improved energy generation maximization techniques for photovoltaic systems," in Proceedings of the Asia-Pacific Power and Energy Engineering Conference (APPEEC '12), pp. 1-5, Shanghai, China, March 2012.

[34] G. J. Yu, Y. S. Jung, J. Y. Choi, I. Choy, J. H. Song, and G. S. Kim, "A novel two-mode MPPT control algorithm based on comparative study of existing algorithms," in Proceedings of the Conference Record of the 29th IEEE Photovoltaic Specialists Conference, pp. 1531-1534, IEEE, May 2002.

[35] A. Al Nabulsi, R. Dhaouadi, and H. Rehman, "Single Input Fuzzy Controller (SFLC) based maximum power point tracking," in Proceedings of the 4th International Conference on IEEE Modeling, Simulation and Applied Optimization (ICMSAO '11), pp. 1-5, Kuala Lumpur, Malaysia, April 2011.

[36] A. Patel, V. Kumar, and Y. Kumar, "Perturb and observe maximum power point tracking for Photovoltaic cell," Innovative Systems Design and Engineering, vol. 4, no. 6, pp. 9-15, 2013.

[37] T. H. Tuffaha, M. Babar, Y. Khan, and N. H. Malik, "Comparative study of different hill climbing MPPT through simulation and experimental test bed," Research Journal of Applied Sciences, Engineering and Technology, vol. 7, no. 20, pp. 4258-4263, 2014.

[38] M. Quamruzzaman and K. M. Rahman, "A modified perturb and observe maximum power point tracking technique for single-stage grid-connected photovoltaic inverter," WSEAS Transactions on Power Systems, vol. 9, pp. 111-118, 2014.

[39] N. Femia, G. Petrone, G. Spagnuolo, and M. Vitelli, “Optimization of perturb and observe maximum power point tracking method," IEEE Transactions on Power Electronics, vol. 20, no. 4, pp. 963-973, 2005.

[40] S. Go, S. Ahn, J. Choi, W. Jung, S. Yun, and I. Song, "Simulation and analysis of existing MPPT control methods in a PV generation system," Journal of International Council on Electrical Engineering, vol. 1, no. 4, pp. 446-451, 2011.

[41] C. Liu, B. Wu, and R. Cheung, "Advanced algorithm for MPPT control of photovoltaic systems," in Proceedings of the Canadian Solar Building Conference, Montreal, Canada, August 2004.
[42] A. Yafaoui, B. Wu, and R. Cheung, "Implementation of maximum power point tracking algorithm for residential photovoltaic systems," in proceedings of the 2nd Canadian Solar Building Conference, Calgary, Canada, 2007.

[43] J. M. Enrique, J. M. Andújar, and M. A. Bohórquez, "A reliable, fast and low cost maximum power point tracker for photovoltaic applications," Solar Energy, vol. 84, no. 1, pp. 7989, 2010.

[44] A. Al-Amoudi and L. Zhang, "Optimal control of a gridconnected PV system for maximum power point tracking and unity power factor," in Proceedings of the 7th International Conference on Power Electronics and Variable Speed Drives, pp. 80-85, September 1998.

[45] L. Zhang, A. Al-Amoudi, and Y. Bai, "Real-time maximum power point tracking for grid-connected photovoltaic systems," in Proceedings of the 8th IEEE International Conference on Power Electronics and Variable Speed Drives, pp. 124-129, London, UK, September 2000.

[46] H. Patel and V. Agarwal, "MPPT scheme for a PV-fed singlephase single-stage grid-connected inverter operating in CCM with only one current sensor," IEEE Transactions on Energy Conversion, vol. 24, no. 1, pp. 256-263, 2009.

[47] J.-M. Kwon, B.-H. Kwon, and K.-H. Nam, "Grid-connected photovoltaic multistring PCS with PV current variation reduction control," IEEE Transactions on Industrial Electronics, vol. 56, no. 11, pp. 4381-4388, 2009.

[48] C. Liu, K. T. Chau, and X. Zhang, "An efficient windphotovoltaic hybrid generation system using doubly excited permanent-magnet brushless machine," IEEE Transactions on Industrial Electronics, vol. 57, no. 3, pp. 831-839, 2010.

[49] G. Petrone, G. Spagnuolo, and M. Vitelli, "A multivariable perturb-and-observe maximum power point tracking technique applied to a single-stage photovoltaic inverter," IEEE Transactions on Industrial Electronics, vol. 58, no. 1, pp. 76-84, 2011.

[50] Y. Jung, J. So, G. Yu, and J. Choi, "Improved perturbation and observation method (IP\&O) of MPPT control for photovoltaic power systems," in Proceedings of the 31st IEEE Photovoltaic Specialists Conference, pp. 1788-1791, IEEE, Lake buena Vista, Fla, USA, January 2005.

[51] J. Suganya and M. Carolin Mabel, "Maximum power point tracker for a photovoltaic system," in Proceedings of the International Conference on IEEE Computing, Electronics and Electrical Technologies (ICCEET '12), pp. 463-465, March 2012.

[52] H. Radwan and M. Orabi, "The non ideality effect of optimizing the P\&O MPPT algorithm for PV stand-alone applications," in Proceedings of the IEEE 34th International Telecommunications Energy Conference (INTELEC '12), pp. 1-7, October 2012.

[53] L.-R. Chen, C.-H. Tsai, Y.-L. Lin, and Y.-S. Lai, "A biological swarm chasing algorithm for tracking the PV maximum power point," IEEE Transactions on Energy Conversion, vol. 25, no. 2, pp. 484-493, 2010.

[54] N. C. Wang, M. Y. Wu, and G. S. Shi, "Study on characteristics of photovoltaic cells based on MATLAB simulation," in Proceedings of the Asia-Pacific Power and Energy Engineering Conference (APPEEC '11), pp. 1-4, March 2011.

[55] N. M. Razali and N. A. Rahim, "DSP-based maximum peak power tracker using $\mathrm{P} \& \mathrm{O}$ algorithm," in Proceedings of the IEEE 1st Conference on Clean Energy and Technology (CET '11), pp. 34-39, Kuala Lumpur, Malaysia, June 2011.

[56] X. Guo, J. Chen, and Q. Liu, "Real-time and grid-connected control of PV power system," in Proceedings of the International 
Conference on Advanced Power System Automation and Protection (APAP '11), pp. 923-928, IEEE, Beijing, China, October 2011.

[57] S. Chin, J. Gadson, and K. Nordstrom, Maximum Power Point Tracker, Tufts University Department of Electrical Engineering and Computer Science, Medford, Mass, USA, 2003.

[58] G. Spiazzi, S. Buso, and P. Mattavelli, "Analysis of MPPT algorithms for photovoltaic panels based on ripple correlation techniques in presence of parasitic components," in Proceedings of the Brazilian Power Electronics Conference, pp. 88-95, September-October 2009.

[59] J. Huusari and T. Suntio, "Interfacing constraints of distributed maximum power point tracking converters in photovoltaic applications," in Proceedings of the 15th International Power Electronics and Motion Control Conference (EPE/PEMC '12), pp. DS3d.1-1-DS3d.1-7, IEEE, Novi Sad, Serbia, September 2012.

[60] W. Luo and G. Han, "Tracking and controlling of maximum power point application in grid-connected photovoltaic generation system," in Proceedings of the 2nd International Symposium on Knowledge Acquisition and Modeling (KAM '09), vol. 3, pp. 237-240, Wuhan, China, November 2009.

[61] S. Patel and W. Shireen, "Fast converging digital MPPT control for photovoltaic applications," in Proceedings of the IEEE Power and Energy Society General Meeting, pp. 1-6, San Diego, Calif, USA, July 2011.

[62] A. Trejos, C. A. Ramos-Paja, and S. Serna, "Compensation of DC-link voltage oscillations in grid-connected PV systems based on high order dc/dc converters," in Proceedings of the IEEE International Symposium on Alternative Energies and Energy Quality (SIFAE '12), pp. 1-6, Barranquilla, Colombia, October 2012.

[63] E. Koutroulis, K. Kalaitzakis, and N. C. Voulgaris, "Development of a microcontroller-based, photovoltaic maximum power point tracking control system," IEEE Transactions on Power Electronics, vol. 16, no. 1, pp. 46-54, 2001.

[64] Z. Liang, A. Q. Huang, and R. Guo, "High efficiency switched capacitor buck-boost converter for PV application," in Proceedings of the 27th Annual IEEE Applied Power Electronics Conference and Exposition (APEC '12), pp. 1951-1958, Orlando, Fla, USA, February 2012.

[65] A. F. Cupertino, J. T. De Resende, H. A. Pereira, and S. I. Seleme Jr., "A grid-connected photovoltaic system with a maximum power point tracker using passivity-based control applied in a boost converter," in Proceedings of the 10th IEEE/IAS International Conference on Industry Applications (INDUSCON '12), Fortaleza, Brazil, November 2012.

[66] J. Pan, C. Wang, and F. Hong, "Research of photovoltaic charging system with maximum power point tracking," in Proceedings of the International Conference on Electronic Measurement \& Instruments (ICEMI '09), pp. 4-478-4-481, Beijing, China, August 2009.

[67] S. Kamaruzzaman, "Optimization of a stand-alone wind/PV hybrid system to provide electricity for a household in Malaysia," in Proceedings of 4th IASME/WSEAS International Conference on Energy and Environment (EE '09), pp. 435-438, 2009.

[68] J. Appelbaum, "The quality of load matching in a directcoupling photovoltaic system," IEEE Transactions on Energy Conversion, vol. 2, no. 4, pp. 534-541, 1987.

[69] M. M. Saied and M. G. Jaboori, "Optimal solar array configuration and DC motor field parameters for maximum annual output mechanical energy," IEEE Transactions on Energy Conversion, vol. 4, no. 3, pp. 459-465, 1989.

[70] K. Khouzam, L. Khouzam, and P. Groumpos, "Optimum matching of ohmic loads to the photovoltaic array," Solar Energy, vol. 46, no. 2, pp. 101-108, 1991.

[71] Q. Kou, S. A. Klein, and W. A. Beckman, "A method for estimating the long-term performance of direct-coupled PV pumping systems," Solar Energy, vol. 64, no. 1-3, pp. 33-40, 1998.

[72] K. Y. Khouzam, "Optimum load matching in direct-coupled photovoltaic power systems-application to resistive loads," IEEE Transactions on Energy Conversion, vol. 5, no. 2, pp. 265-271, 1990.

[73] L. Cristaldi, M. Faifer, M. Rossi, and S. Toscani, "MPPT definition and validation: a new model-based approach," in Proceedings of the IEEE International Instrumentation and Measurement Technology Conference (I2MTC '12), pp. 594-599, Graz, Austria, May 2012.

[74] T. D. Hund and B. Thompson, "Amp-hour counting charge control for photovoltaic hybrid power systems," in Proceedings of the 26th IEEE Photovoltaic Specialists Conference, pp. 12811284, Anaheim, Calif, USA, September 1997.

[75] S. Krithiga, N. Gounder, and A. Gounden, "Power electronic configuration for the operation of PV system in combined gridconnected and stand-alone modes," IET Power Electronics, vol. 7, no. 3, pp. 640-647, 2014.

[76] S. Duryea, S. Islam, and W. Lawrance, "A battery management system for stand-alone photovoltaic energy systems," IEEE Industry Applications Magazine, vol. 7, no. 3, pp. 67-72, 2001.

[77] R. Giral, C. A. Ramos-Paja, D. Gonzalez, J. Calvente, À. CidPastor, and L. Martinez-Salamero, "Minimizing the effects of shadowing in a PV module by means of active voltage sharing," in Proceedings of the IEEE International Conference on Industrial Technology (ICIT '10), pp. 943-948, IEEE, March 2010.

[78] H. A. B. Siddique, S. M. Ali, and R. W. De Doncker, "DC collector grid configurations for large photovoltaic parks," in Proceedings of the 15th European Conference on Power Electronics and Applications (EPE '13), pp. 1-10, IEEE, Lille, France, September 2013.

[79] G. H. Yordanov, O.-M. Midtgard, and T. O. Saetre, "Ideality factor behavior between the maximum power point and open circuit," in Proceedings of the 39th Photovoltaic Specialists Conference (PVSC '13), pp. 729-733, IEEE, Tampa, Fla, USA, June 2013.

[80] L. Han and L. Jia, "Photovoltaic power generation system MPPT," in Proceedings of the IEEE 5th International Conference on Advanced Computational Intelligence (ICACI '12), pp. 919922, Nanjing, China, October 2012.

[81] A. O. Ibrahim and O. Basir, "A novel sensorless support vector regression based multi-stage algorithm to track the maximum power point for photovoltaic systems," in Proceedings of the IEEE Power and Energy Society General Meeting (PES '13), pp. 1-5, IEEE, Vancouver, Canada, July 2013.

[82] L. Ciabattoni, M. Grisostomi, G. Ippoliti, and S. Longhi, "Neural networks based home energy management system in residential PV scenario," in Proceedings of the 39th IEEE Photovoltaic Specialists Conference (PVSC '13), pp. 1721-1726, June 2013.

[83] L. L. Jiang, D. R. Nayanasiri, D. L. Maskell, and D. M. Vilathgamuwa, "A simple and efficient hybrid maximum power point tracking method for PV systems under partially shaded condition," in Proceedings of the 39th Annual Conference of the IEEE Industrial Electronics Society (IECON '13), pp. 1513-1518, Vienna, Austria, November 2013. 
[84] H. H. Lee, L. M. Phuong, P. Q. Dzung, N. T. Dan Vu, and L. D. Khoa, "The new maximum power point tracking algorithm using ANN-based solar PV systems," in Proceedings of the IEEE Region 10 Conference (TENCON '10), pp. 2179-2184, Fukuoka, Japan, November 2010.

[85] M. Sheraz and M. A. Abido, "An efficient MPPT controller using differential evolution and neural network," in Proceedings of the IEEE International Conference on Power and Energy (PECon '12), pp. 378-383, IEEE, Kota Kinabalu, Malaysia, December 2012.

[86] Q. D. Phan, D. K. Le, H. L. Hong, M. P. Le, and N. T. D. Vu, “The new MPPT algorithm using ANN-based PV," in Proceedings of the International Forum on Strategic Technology (IFOST '10), pp. 402-407, Ulsan, Republic of Korea, October 2010.

[87] J. Xu, A. Shen, C. Yang, W. Rao, and X. Yang, "ANN based on IncCond algorithm for MPP tracker," in Proceedings of the 6th International Conference on Bio-Inspired Computing: Theories and Applications (BIC-TA '11), pp. 129-134, Penang, Malaysia, September 2011.

[88] L. Jie and C. Ziran, "Research on the MPPT algorithms of photovoltaic system based on PV neural network," in Proceedings of the Chinese Control and Decision Conference (CCDC '11), pp. 1851-1854, IEEE, Mianyang, China, May 2011.

[89] A. Durgadevi, S. Arulselvi, and S. P. Natarajan, "Photovoltaic modeling and its characteristics," in Proceedings of the International Conference on Emerging Trends in Electrical and Computer Technology (ICETECT '11), pp. 469-475, IEEE, Tamil Nadu, India, March 2011.

[90] L. M. Elobaid, A. K. Abdelsalam, and E. E. Zakzouk, "Artificial neural network based maximum power point tracking technique for PV systems," in Proceedings of the 38th Annual Conference on IEEE Industrial Electronics Society (IECON '12), pp. 937-942, IEEE, Montreal, Canada, October 2012.

[91] L. L. Jiang, D. R. Nayanasiri, D. L. Maskell, and D. M. Vilathgamuwa, "A simple and efficient hybrid maximum power point tracking method for PV systems under partially shaded condition," in Proceedings of the 39th Annual Conference of the IEEE Industrial Electronics Society (IECON '13), pp. 1513-1518, IEEE, Vienna, Austria, November 2013.

[92] N. Zhang, P. K. Behera, and C. Williams, "Solar radiation prediction based on particle swarm optimization and evolutionary algorithm using recurrent neural networks," in Proceedings of the 7th Annual IEEE International Systems Conference (SysCon '13), pp. 280-286, Orlando, Fla, USA, April 2013.

[93] Y.-H. Chiu, Y.-F. Luo, J.-W. Huang, and Y.-H. Liu, "An ANNbased maximum power point tracking method for fast changing environments," in Proceedings of the Joint International Conference on IEEE Soft Computing and Intelligent System (SCIS '12) and 13th International Symposium on Advanced Intelligent System (ISAIS '12), pp. 715-720, November 2012.

[94] K. Yamauchi, "Incremental learning on a budget and its application to quick maximum power point tracking of photovoltaic systems," in Proceedings of the Joint 6th International Conference on IEEE Soft Computing and Intelligent Systems (SCIS '12) and 13th International Symposium on Advanced Intelligent Systems (ISIS '12), pp. 71-78, Kobe, Japan, November 2012.

[95] S. D. Anitha and S. B. J. Prabha, "Artificial Neural Network based maximum power point tracker for photovoltaic system," in Proceedings of the International Conference on Sustainable Energy and Intelligent Systems (SEISCON '11), pp. 130-136, IET, Chennai, India, 2011.

[96] Z. Yong, L. Hong, L. Liqun, and G. XiaoFeng, “The MPPT control method by using BP neural networks in PV generating system ", in Proceedings of the International Conference on Industrial Control and Electronics Engineering (ICICEE '12), pp. 1639-1642, IEEE, Xi'an, China, 2012.

[97] R. Ramaprabha, B. L. Mathur, and M. Sharanya, "Solar array modeling and simulation of MPPT using neural network," in Proceedings of the International Conference on Control Automation, Communication and Energy Conservation (INCACEC '09), pp. 1-5, IEEE, Perundurai, India, June 2009.

[98] H. Afghoul, F. Krim, and D. Chikouche, "Increase the photovoltaic conversion efficiency using Neuro-fuzzy control applied to MPPT," in Proceedings of the 1st International Renewable and Sustainable Energy Conference (IRSEC '13), pp. 348-353, Ouarzazate, Morocco, March 2013.

[99] S. Sreekumar and A. Benny, "Maximum power point tracking of photovoltaic system using fuzzy logic controller based boost converter," in Proceedings of the International Conference on Current Trends in Engineering and Technology (ICCTET '13), pp. 275-280, IEEE, Coimbatore, India, July 2013.

[100] A. Mellit, A. H. Arab, N. Khorissi, and H. Salhi, "An ANFISbased forecasting for solar radiation data from sunshine duration and ambient temperature," in Proceedings of the Power Engineering Society General Meeting, pp. 1-6, IEEE, Tampa, Fla, USA, June 2007.

[101] M. I. Hossain, S. A. Khan, M. Shafiullah, and M. J. Hossain, "Design and implementation of MPPT controlled grid connected photovoltaic system," in Proceedings of the IEEE Symposium on Computers and Informatics (ISCI '11), pp. 284289, IEEE, Kuala Lumpur, Malaysia, March 2011.

[102] A. A. Nabulsi, R. Dhaouadi, and H.-U. Rehman, "Single input fuzzy controller (SFLC) based maximum power point tracking," in Proceedings of the 4th International Conference on Modeling, Simulation and Applied Optimization (ICMSAO '11), pp. 1-5, IEEE, Kuala Lumpur, Malaysia, April 2011.

[103] S. Hadjammar and F. Bouchafaa, "Performances of PV system connected to the grid with MPPT controlled by fuzzy control," in Proceedings of the IEEE International Conference on Smart Energy Grid Engineering (SEGE '13), pp. 1-7, Oshawa, Canada, August 2013.

[104] A. Mellit and S. A. Kalogirou, "Neuro-fuzzy based modeling for photovoltaic power supply system," in Proceedings of the IEEE International Power and Energy Conference, pp. 88-93, IEEE, Putrajaya, Malaysia, November 2006.

[105] Y. Wang, H. Yang, A. Li, and Y. Wang, "Research of photovoltaic and PHEV hybrid management system based on hierarchical fuzzy control," in Proceedings of the 8th International Conference on Electrical Engineering, Computing Science and Automatic Control (CCE '11), pp. 1-5, IEEE, Mérida, Mexico, October 2011.

[106] C. S. Chin, Y. K. Chin, B. L. Chua, A. Kiring, and K. T. K. Teo, "Fuzzy logic based MPPT for pv array under partially shaded conditions," in Proceedings of the International Conference on Advanced Computer Science Applications and Technologies (ACSAT '12), pp. 133-138, Kuala Lumpur, Malaysia, November 2012.

[107] A. Iqbal, H. Abu-Rub, and S. M. Ahmed, "Adaptive neurofuzzy inference system based maximum power point tracking of a solar PV module," in Proceedings of the IEEE International Energy Conference and Exhibition (EnergyCon '10), pp. 51-56, Manama, Bahrain, December 2010.

[108] A. A. Kulaksiz and Ö. Aydoğdu, "ANN-based maximum power point tracking of photovoltaic system using fuzzy controller," in Proceedings of the International Symposium on Innovations in 
Intelligent Systems and Applications (INISTA '12), pp. 1-5, July 2012.

[109] O. Cigdem, E. Kayacan, and O. Kaynak, "Experimental study of an interval type-2 fuzzy neural network using sliding-mode online learning algorithm," in Proceedings of the 8th IEEE Asian Control Conference (ASCC '11), pp. 1181-1186, Kaohsiung, Taiwan, May 2011.

[110] C.-S. Chiu and Y.-L. Ouyang, "Robust maximum power tracking control of uncertain photovoltaic systems: a unified T-S fuzzy model-based approach," IEEE Transactions on Control Systems Technology, vol. 19, no. 6, pp. 1516-1526, 2011.

[111] Subiyanto, A. Mohamed, and M. A. Hannan, "Maximum power point tracking in grid connected PV system using a novel fuzzy logic controller," in Proceedings of the IEEE Student Conference on Research and Development (SCOReD '09), pp. 349-352, IEEE, Serdang, Malaysia, November 2009.

[112] M. Abdulkadir, A. H. M. Yatim, and S. T. Yusuf, "An improved PSO-based MPPT control strategy for photovoltaic systems," International Journal of Photoenergy, vol. 2014, Article ID 818232, 11 pages, 2014.

[113] K. Ishaque, Z. Salam, M. Amjad, and S. Mekhilef, "An improved particle swarm optimization (PSO)-based MPPT for PV with reduced steady-state oscillation," IEEE Transactions on Power Electronics, vol. 27, no. 8, pp. 3627-3638, 2012.

[114] H.-T. Yau, C.-J. Lin, and Q.-C. Liang, "PSO based PI controller design for a solar charger system," The Scientific World Journal, vol. 2013, Article ID 815280, 13 pages, 2013.

[115] K.-H. Chao, L.-Y. Chang, and H.-C. Liu, "Maximum power point tracking method based on modified particle swarm optimization for photovoltaic systems," International Journal of Photoenergy, vol. 2013, Article ID 583163, 6 pages, 2013.

[116] Y.-H. Liu, S.-C. Huang, J.-W. Huang, and W.-C. Liang, "A particle swarm optimization-based maximum power point tracking algorithm for PV systems operating under partially shaded conditions," IEEE Transactions on Energy Conversion, vol. 27, no. 4, pp. 1027-1035, 2012.

[117] M. Abdulkadir, A. S. Samosir, and A. H. M. Yatim, "Modelling and simulation of maximum power point tracking of photovoltaic system in Simulink model," in Proceedings of the IEEE International Conference on Power and Energy (PECon '12), pp. 325-330, Kota Kinabalu, Malaysia, December 2012.

[118] M. Abdulkadir, A. S. Samosir, A. H. M. Yatin, and S. T. Yusuf, "A new approach of modeling simulation of MPPT for photovoltaic system in simulink model," ARPN Journal of Engineering and Applied Sciences, vol. 8, no. 7, pp. 488-494, 2013.

[119] M. Abdulkadir, A. S. Samosir, and A. H. M. Yatim, "Modeling and simulation of a solar photovoltaic system, its dynamics and transient characteristics in LABVIEW," International Journal of Power Electronics and Drive Systems, vol. 3, no. 2, pp. 185-192, 2013.

[120] M. Miyatake, F. Toriumi, T. Endo, and N. Fujii, "A novel maximum power point tracker controlling several converters connected to photovoltaic arrays with particle swarm optimization technique," in Proceedings of the European Conference on Power Electronics and Applications (EPE '07), pp. 1-10, Aalborg, Denmark, September 2007.

[121] L. Wu, Z. Zhao, and J. Liu, "A single-stage three-phase gridconnected photovoltaic system with modified MPPT method and reactive power compensation," IEEE Transactions on Energy Conversion, vol. 22, no. 4, pp. 881-886, 2007.
[122] L. Piegari and R. Rizzo, "Adaptive perturb and observe algorithm for photovoltaic maximum power point tracking," IET Renewable Power Generation, vol. 4, no. 4, pp. 317-328, 2010.

[123] N. A. Azli, Z. Salam, A. Jusoh, M. Facta, B. C. Lim, and S. Hossain, "Effect of fill factor on the MPPT performance of a grid-connected inverter under Malaysian conditions," in Proceedings of the IEEE 2nd International Power and Energy Conference (PECon '08), pp. 460-462, IEEE, Johor Bahru, Malaysia, December 2008.

[124] M. Tauseef and E. Nowicki, "A simple and cost effective maximum power point tracker for PV arrays employing a novel constant voltage technique," in Proceedings of the 25th IEEE Canadian Conference on Electrical and Computer Engineering (CCECE '12), pp. 1-4, IEEE, Montreal, Canada, May 2012.

[125] P. Mattavelli, S. Saggini, E. Orietti, and G. Spiazzi, "A simple mixed-signal MPPT circuit for photovoltaic applications," in Proceedings of the 25th Annual IEEE Applied Power Electronics Conference and Exposition (APEC '10), pp. 953-960, IEEE, Palm Springs, Calif, USA, February 2010.

[126] H. Al-Bahadili, H. Al-Saadi, R. Al-Sayed, and M. A. S. Hasan, "Simulation of maximum power point tracking for photovoltaic systems," in Proceedings of the 1st International Conference \& Exhibition on the Applications of Information Technology to Renewable Energy Processes and Systems (IT-DREPS), pp. 7984, Amman, Jordan, 2013.

[127] X. Wu, Z. Cheng, and X. Wei, "A study of maximum power point tracking in novel small-scale photovoltaic LED lighting systems," in Proceedings of the International Conference on Artificial Intelligence and Computational Intelligence (AICI '09), pp. 40-43, Shanghai, China, November 2009.

[128] M. E. Ropp and S. Gonzalez, "Development of a MAT$\mathrm{LAB} /$ simulink model of a single-phase grid-connected photovoltaic system," IEEE Transactions on Energy Conversion, vol. 24, no. 1, pp. 195-202, 2009.

[129] G. Brando, A. Dannier, and R. Rizzo, "A sensorless control of Hbridge multilevel converter for maximum power point tracking in grid connected photovoltaic systems," in Proceedings of the International Conference on Clean Electrical Power (ICCEP '07), pp. 789-794, Capri, Italy, May 2007.

[130] S. A. Khan and M. I. Hossain, "Design and implementation of microcontroller based fuzzy logic control for maximum power point tracking of a photovoltaic system," in Proceedings of the International Conference on Electrical and Computer Engineering (ICECE '10), pp. 322-325, IEEE, Dhaka, Bangladesh, December 2010.

[131] R. Kadri, J.-P. Gaubert, and G. Champenois, "An Improved maximum power point tracking for photovoltaic grid-connected inverter based on voltage-oriented control," IEEE Transactions on Industrial Electronics, vol. 58, no. 1, pp. 66-75, 2011.

[132] N. G. M. Thao and K. Uchida, "Control the photovoltaic grid-connected system using fuzzy logic and backstepping approach," in Proceedings of the 9th Asian Control Conference (ASCC '13), pp. 1-8, IEEE, Istanbul, Turkey, June 2013.

[133] S. Jain and V. Agarwal, "A single-stage grid connected inverter topology for solar PV systems with maximum power point tracking," IEEE Transactions on Power Electronics, vol. 22, no. 5, pp. 1928-1940, 2007.

[134] M. Calais, J. Myrzik, T. Spooner, and V. G. Agelidis, "Inverters for single-phase grid connected photovoltaic systemsan overview," in Proceedings of the IEEE 33rd Annual Power Electronics Specialists Conference (PESC '02), vol. 4, pp. 19952000, Cairns, Australia, June 2002. 
[135] I. Bhattacharya, Y. Deng, and S. Y. Foo, "Active filters for harmonics elimination in solar Photovoltaic grid-connected and stand-alone systems," in Proceedings of the 2nd Asia Symposium on Quality Electronic Design (ASQED '10), pp. 280-284, IEEE, Penang, Malaysia, August 2010.

[136] D. Rivas, L. Morán, J. W. Dixon, and J. R. Espinoza, "Improving passive filter compensation performance with active techniques," IEEE Transactions on Industrial Electronics, vol. 50, no. 1, pp. 161-170, 2003.

[137] S. N. A. L. Yousif, M. Z. C. Wanik, and A. Mohamed, "Implementation of different passive filter designs for harmonic mitigation," in Proceedings of the National Power and Energy Conference (PECon '04), pp. 229-234, IEEE, Kuala Lumpur, Malaysia, November 2004.

[138] C. M. Chovitia, N. P. Gupta, and P. N. Gupta, "Harmonic mitigation using shunt active filter at utility end in grid connected to renewable source of energy," International Journal of Emerging technology and Advanced Engineering, vol. 2, no. 8, pp. 230-235, 2012.

[139] A. Blorfan, D. Flieller, P. Wira, G. Sturtzer, and J. Merckle, "A new approach for modeling the photovoltaic cell using orcad comparing with the model done in Matlab," International Review on Modelling and Simulations, vol. 3, no. 5, pp. 948-954, 2010.

[140] F. Khoucha, A. Benrabah, O. Herizi, A. Kheloui, and M. E. H. Benbouuzid, "An improved MPPT interleaved boost converter for fast solar electric vehicle applications," in Proceedings of the IEEE Power Engineering, Energy and Electrical Drives (POWERENG '13), pp. 1076-1081, Istanbul, Turkey, May 2013.

[141] L. Nousiainen and T. Suntio, "Dynamic characteristics of current-fed semi-quadratic buck-boost converter in photovoltaic applications," in Proceedings of the 3rd Annual IEEE Energy Conversion Congress and Exposition (ECCE '11), pp. 10311038, Phoenix, Ariz, USA, September 2011.

[142] M. A. Akhtar and H. P. Ikkurti, "A new controller for maximum power Extraction from photovoltaic system using Phase Modulated Converter," in Proceedings of the International Conference on Advances in Power Conversion and Energy Technologies (APCET '12), pp. 1-6, Mylavaram, India, August 2012.

[143] V. Mummadi, "Fourth order buck converter for photovoltaic maximum power point tracking applications," in Proceedings of the IEEE International Conference on Sustainable Energy Technologies, pp. 295-300, Singapore, November 2008.

[144] Z. Liang, A. Q. Huang, and R. Guo, "High efficiency switched capacitor buck-boost converter for PV application," in Proceedings of the 27th Annual IEEE Applied Power Electronics Conference and Exposition (APEC '12), pp. 1951-1958, IEEE, Orlando, Fla, USA, February 2012.

[145] N. Tummuru, M. K. Mishra, and S. Srinivas, "Fourth order coupled inductor boost converter topology for solar PV tracking applications," in Proceedings of the Annual IEEE India Conference (INDICON '13), pp. 1-6, IEEE, Mumbai, India, December 2013.

[146] G. Brando, A. Dannier, and R. Rizzo, "A sensorless control of Hbridge multilevel converter for maximum power point tracking in grid connected photovoltaic systems," in Proceedings of the International Conference on Clean Electrical Power (ICCEP '07), pp. 789-794, IEEE, Capri, Italy, May 2007.

[147] C. Boonmee and Y. Kumsuwan, "Modified maximum power point tracking based-on ripple correlation control application for single-phase VSI grid-connected PV systems," in Proceedings of the 10th International Conference on Electrical Engineering/Electronics, Computer, Telecommunications and Information Technology (ECTI-CON '13), pp. 1-6, IEEE, Krabi, Thailand, May 2013.

[148] S.-F. He, L.-Z. Yi, J.-C. Li, Z.-Z. Yao, and H.-M. Peng, "Design of three-phase photovoltaic grid connected inverter based on RBF neural network," in Proceedings of the 1st IEEE International Conference on Sustainable Power Generation and Supply (SUPERGEN '09), pp. 1-5, Nanjing, China, April 2009.

[149] M. H. Nehrir, B. J. LaMeres, G. Venkataramanan, V. Gerez, and L. A. Alvarado, "An approach to evaluate the general performance of stand-alone wind/photovoltaic generating systems," IEEE Transactions on Energy Conversion, vol. 15, no. 4, pp. 433439, 2000.

[150] B. Kroposki, R. Lasseter, T. Ise, S. Morozumi, S. Papathanassiou, and N. Hatziargyriou, "Making microgrids work," IEEE Power and Energy Magazine, vol. 6, no. 3, pp. 40-53, 2008.

[151] L. M. Tolbert, F. Z. Peng, and T. G. Habetler, "Multilevel converters for large electric drives," IEEE Transactions on Industry Applications, vol. 35, no. 1, pp. 36-44, 1999.

[152] http://www.Energybible.com/solarenergy/Inverters.html.

[153] European Photovoltaic Industry Association Global market outlook for photovoltaics until 2016, 2016, http://www.epia.org.

[154] S. B. Kjaer, J. K. Pedersen, and F. Blaabjerg, "A review of singlephase grid-connected inverters for photovoltaic modules," IEEE Transactions on Industry Applications, vol. 41, no. 5, pp. 12921306, 2005.

[155] Q. Li and P. Wolfs, "A review of the single phase photovoltaic module integrated converter topologies with three different DC link configurations," IEEE Transactions on Power Electronics, vol. 23, no. 3, pp. 1320-1333, 2008.

[156] Y. Xue, L. Chang, S. B. Kjær, J. Bordonau, and T. Shimizu, "Topologies of single-phase inverters for small distributed power generators: an overview," IEEE Transactions on Power Electronics, vol. 19, no. 5, pp. 1305-1314, 2004.

[157] B. Seal, "Specification for smart inverter interactions with the electric grid using International Electrochemical Commission 61850," Standard 1021674, Electric Power Research Institute, Knoxville, Tenn, USA, 2010.

[158] K. Turistsyn, P. Sulc, S. Bachaus, and M. Chertkov, "Local control of reactive power by distributed photovoltaic generators," in Proceedings of the 1st IEEE International Conference on Smart Grid Communications (SmartGridComm '10), pp. 79-84, IEEE, Gaithersburg, Md, USA, 2010.

[159] J. W. Smith, W. Sunderman, R. Dugan, and B. Seal, "Smart inverter volt/var control functions for high penetration of PV on distribution systems," in Proceedings of the IEEE/PES Power Systems Conference and Exposition (PSCE '11), pp. 1-6, Phoenix, Ariz, USA, March 2011.

[160] T. Blank and S. Thomas, "Modular energy storage," in Annual Report 2009, pp. 192-193, EON Energy Research Centre, Aachen, Germany, 2009.

[161] C. Cavallaro, S. Musumeci, C. Santonocito, and M. Pappalardo, "Smart photovoltaic UPS system for domestic appliances," in Proceedings of the International Conference on Clean Electrical Power (ICCEP '09), pp. 699-704, IEEE, Capri, Italy, June 2009.

[162] S. Nonaka and K. Harada, "Application of utility interactive photovoltaic power generation system for UPS," Solar Energy Materials and Solar Cells, vol. 47, no. 1-4, pp. 271-279, 1997. 
[163] S. Daher, J. Schmid, and F. L. M. Antunes, "Multilevel inverter topologies for stand-alone PV systems," IEEE Transactions on Industrial Electronics, vol. 55, no. 7, pp. 2703-2712, 2008.

[164] F.-S. Kang, S. E. Cho, S.-J. Park, C.-U. Kim, and T. Ise, "A new control scheme of a cascaded transformer type multilevel PWM inverter for a residential photovoltaic power conditioning system," Solar Energy, vol. 78, no. 6, pp. 727-738, 2005.

[165] A. Yazdani and P. P. Dash, "A control methodology and characterization of dynamics for a photovoltaic (PV) system interfaced with a distribution network," IEEE Transactions on Power Delivery, vol. 24, no. 3, pp. 1538-1551, 2009.

[166] M. A. Abdullah, A. H. M. Yatim, C. W. Tan, and R. Saidur, "A review of maximum power point tracking algorithms for wind energy systems," Renewable and Sustainable Energy Reviews, vol. 16, no. 5, pp. 3220-3227, 2012.

[167] A. Yazdani, A. R. Di Fazio, H. Ghoddami et al., "Modeling guidelines and a benchmark for power system simulation studies of three-phase single-stage photovoltaic systems," IEEE Transactions on Power Delivery, vol. 26, no. 2, pp. 1247-1264, 2011.

[168] M. Bragard, N. Soltau, S. Thomas, and R. W. De Doncker, "The balance of renewable sources and user demands in grids: power electronics for modular battery energy storage systems," IEEE Transactions on Power Electronics, vol. 25, no. 12, pp. 3049-3056, 2010.

[169] O. Bohlen, Impedance-based battery monitoring [Ph.D. dissertation], Institute Fuer Leistungselektronik and Elektrische Antriebe, RWTH Aachen University, Aachen, Germany, 2008.

[170] C.-H. Dustmann, "Advances in ZEBRA batteries," Journal of Power Sources, vol. 127, no. 1-2, pp. 85-92, 2004.

[171] T. Blank, S. Thomas, C. Roggendorf, T. Pollok, I. Trintis, and D. U. Sauer, "Design and construction of a test bench to characterize efficiency and reliability of high voltage battery energy storage systems," in Proceedings of the IEEE International Telecommunications Energy Conference (INTELEC '10), pp. 1-7, IEEE, Orlando, Fla, USA, June 2010.

[172] S. Thomas, T. Blank, D. U. Sauer, and R. W. D. Doncker, "DC/DC converter with high transformation ratio for characterization of high-voltage batteries up to $6 \mathrm{kV}$ for modular energy storage systems in medium-voltage grids," in Proceedings of the International ETG-Kongress, vol. 27, 2009.

[173] D. Magnor, J. B. Gerschler, E. M. Merk, and D. U. Sauer, "Concept of a battery aging model for lithium-ion batteries considering the lifetime dependency on the operation strategy," in Processing 24th European Photovoltaic Solar Energy Conference and Exhibition, pp. 3128-3134, Hamburg, Germany, September 2009.

[174] T. Logeswaran and A. Senthilkumar, "A review of maximum power point tracking algorithms for photovoltaic systems under uniform and non-uniform irradiances," in Proceedings of the 4th International Conference on Advances in Energy Research (ICAER '13), pp. 228-235, Mumbai, India, December 2013.

[175] D. Sukumar, J. Jithendranath, and S. Saranu, "Three-level inverter-fed induction motor drive performance improvement with neuro-fuzzy space vector modulation," Electric Power Components and Systems, vol. 42, no. 15, pp. 1633-1646, 2014.

[176] S. Kohsri and B. Plangklang, "Energy management and control system for smart renewable energy remote power generation," Energy Procedia, vol. 9, pp. 198-206, 2011.
[177] M. Alonso, H. Amaris, and C. Alvarez-Ortega, "Integration of renewable energy sources in smart grids by means of evolutionary optimization algorithms," Expert Systems with Applications, vol. 39, no. 5, pp. 5513-5522, 2012.

[178] B. B. Alagoz, A. Kaygusuz, and A. Karabiber, "A user-mode distributed energy management architecture for smart grid applications," Energy, vol. 44, no. 1, pp. 167-177, 2012.

[179] V. C. Güngör, D. Sahin, T. Kocak et al., "Smart grid technologies: communication technologies and standards," IEEE Transactions on Industrial Informatics, vol. 7, no. 4, pp. 529-539, 2011.

[180] B. Pakkiraiah and G. Durga Sukumar, "A new modified MPPT controller for solar photovoltaic system," in Proceedings of the IEEE International Conference on Research in Computational Intelligence and Communication Networks (ICRCICN '15), pp. 294-299, Kolkata, India, November 2015.

[181] B. Pakkiraiah and G. D. Sukumar, "A new modified MPPT controller for improved performance of an asynchronous motor drive under variable irradiance and variable temperature," International Journal of Computers and Applications, 2016.

[182] T. Kaur, "Solar PV integration in smart grid-issues and challenges," International Journal of Advanced Research in Electrical, Electronics and Instrumentation Engineering, vol. 4, no. 7, pp. 5861-5865, 2015.

[183] “Advantages and disadvantages of solar PV system," http://www .greenpower-technology.co.uk/solar-pv. 

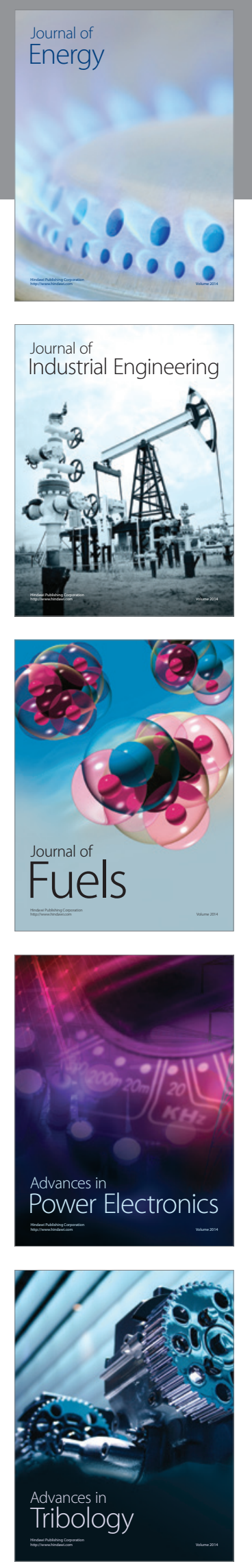
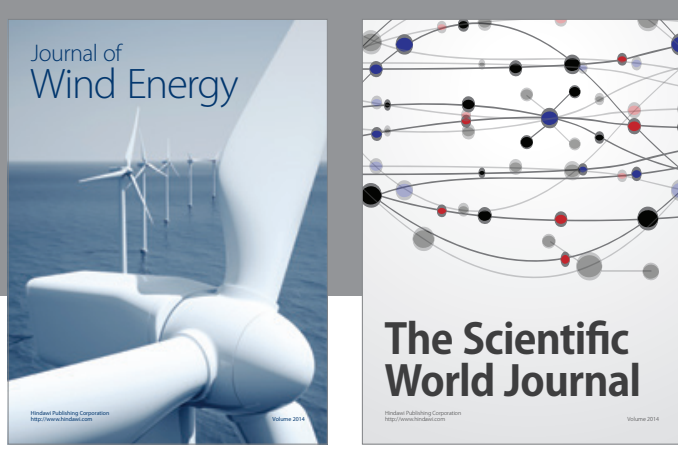

The Scientific World Journal
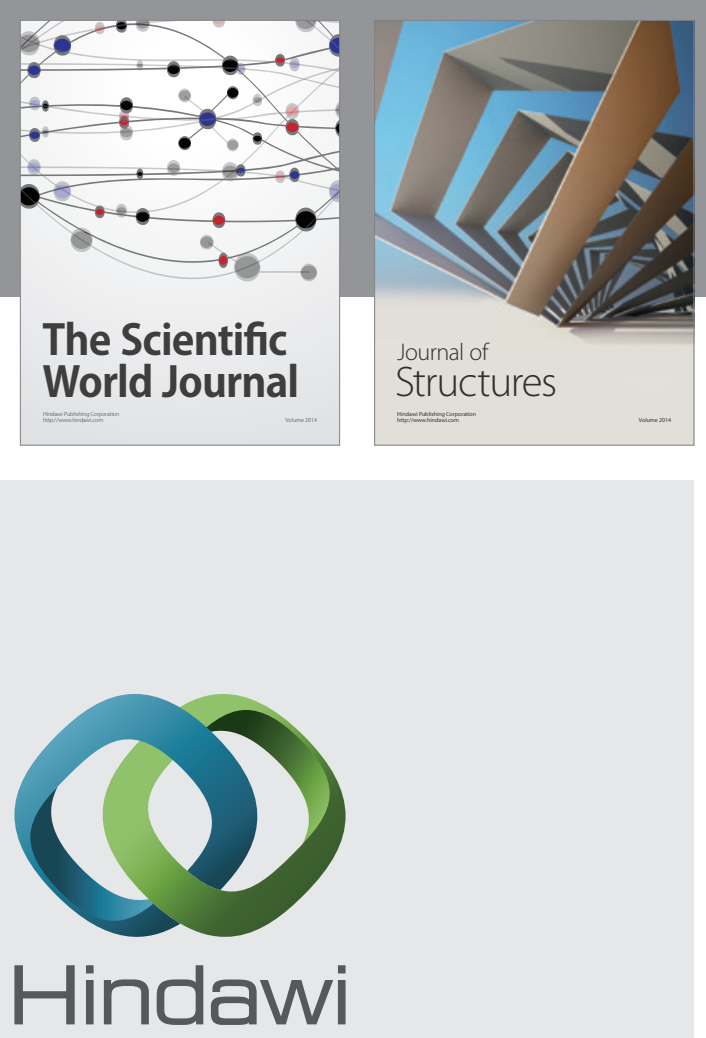

Submit your manuscripts at

http://www.hindawi.com
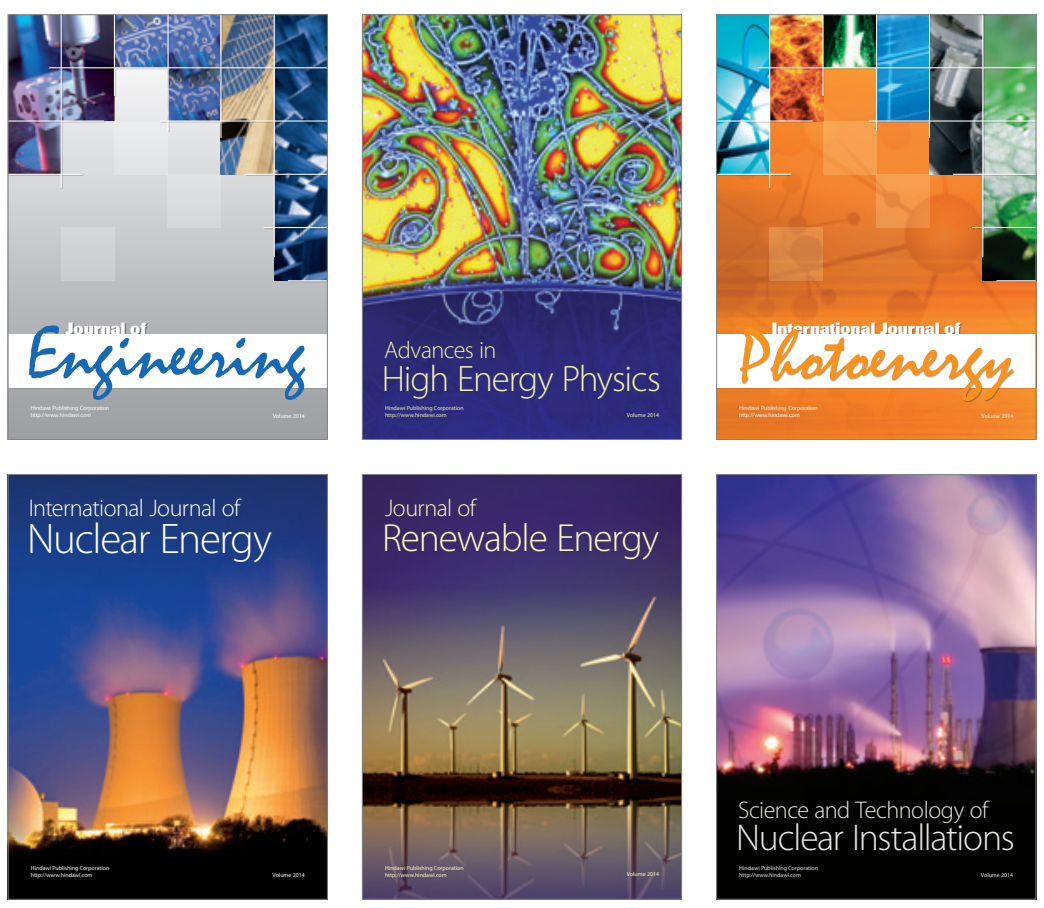
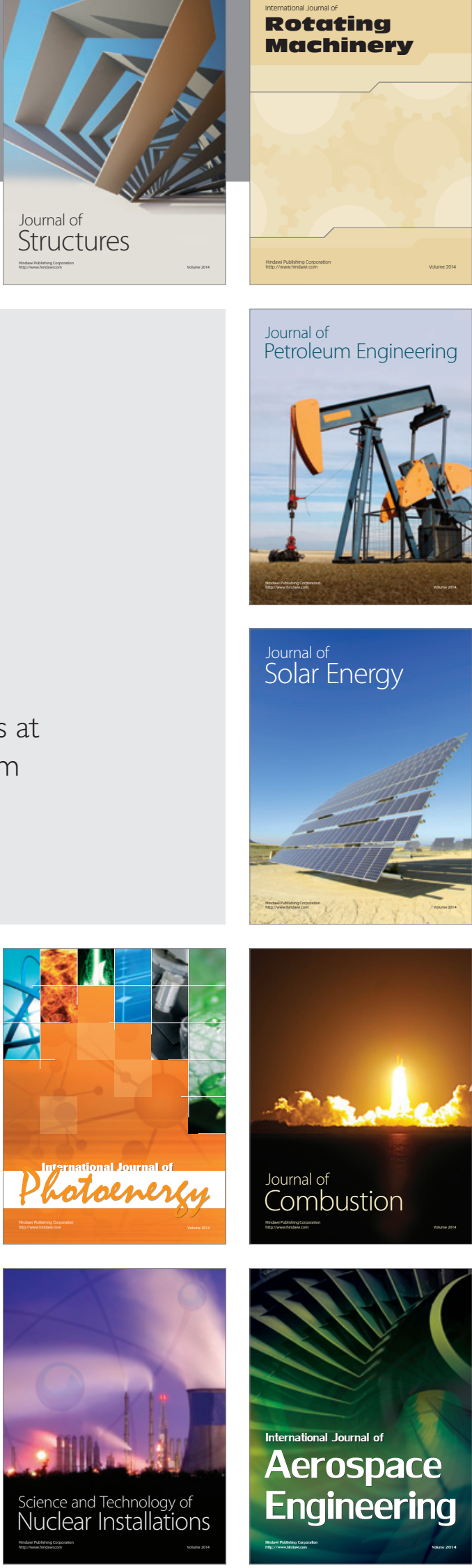